\title{
やや長周期地震動の距離減衰式と 全国の地点補正倍率
}

\author{
片岡 正次郎 1 ・松本 俊輔 2 ・日下部 毅明 3 ・遠山 信彦4 \\ 1正会員 国土交通省 国土技術政策総合研究所地震防災研究室 主任研究官 \\ （テ305-0804 茨城県つくば市旭1） \\ E-mail: kataoka-s92re@nilim.go.jp \\ 2正会員 国土交通省 国土技術政策総合研究所道路研究室 研究官 \\ （元 国土技術政策総合研究所地震防災研究室 研究官） \\ （テ305-0804 茨城県つくば市旭1） \\ 3正会員 国土交通省 北海道開発局建設部道路維持課 道路防災対策官 \\ （元 国土技術政策総合研究所地震防災研究室 室長） \\ (干060-8511 札幌市北区北8条西2丁目第1合同庁舎) \\ 4非会員 応用地質株式会社 東京本社技術センター地震防災部 \\ （テ305-0841 茨城県つくば市御幸が丘43）
}

\begin{abstract}
既往の観測記録をもとに，周期 2～20秒のやや長周期地震動の加速度応答スペクトル（減衰定数 $1,5 \%$ ) と加速度フーリエスペクトルを推定する距離減衰式を作成した。距離減衰式を作成する際の回帰分析で得 られる観測点補正值をもとに，全国における地点補正倍率を算定した。 三次元差分法で計算されたやや長 周期地震動と比較することにより，距離減衰式と地点補正倍率の妥当性を検討した。さらに，東海・東南 海・南海連動地震発生時のやや長周期地震動を試算した。これにより，日本全国の任意の点におけるやや 長周期地震動の推定が，サイトスペシフィック，かつ簡便に可能であることを示した.
\end{abstract}

Key Words : attenuation relationship, ground motion, rather-long period, amplification map

\section{1. はじめに}

マグニチュード 8 程度以上の巨大地震では，震源 域から数百 $\mathrm{km}$ 離れた地点でも, 大きな振幅のやや 長周期地震動（周期数秒〜数十秒程度）が観測され ている. 減衰の小さい長周期構造物は, その固有周 期と地震動の周期が一致すると共振し，使用性や安 全性に影響を及ぼす可能性がある。このような構造 物への影響を検討する上では，地点ごとにどの周期 帯の地震動が，どの程度大きくなるかを予測するこ とが必要とされる.

やや長周期地震動は, 短周期の地震動ほど微細な 震源過程や地下構造に影響されないため, 差分法を 中心とした理論的手法による高精度の予測が期待さ れている1), 2)。とはいえ, 現状では関東平野や大阪 平野のように地下構造が比較的明らかになっている 地域は少なく, モデル化や数值計算に多大な労力が 必要なため, わが国のどこで, どの周期帯の地震動 がどの程度増幅されるかは理論的手法では明らかに
されていない.

一方, 距離減衰式による地震動強さの推定では, 複雑な震源過程などを考慮することはできないが, 実際に観測された地震動強さに直接基づいたもので あることから，距離減衰式は依然信頼性の高い地震 動推定手法の一つである. 距離減衰式が観測記録の 平均的な傾向を表現したものであることを利用し， そこからのずれに基づいて観測点ごとにやや長周期 地震動の摇れやすさを推定することも行われている 例えば岡田・鏡味 $\left.{ }^{3}\right)$ は気象庁一倍強震計等の記録を もとに震央距離を指標とする距離減衰式を求め, 各 観測点の最大変位の距離減衰式からのずれに基づい て，全国94観測点におけるやや長周期での地盤の摇 れや寸さを算出した。 その結果から, やや長周期で の摇れや寸さが深い地盤条件に影響されること等を 指摘している. Mamula et $\left.\mathrm{al}^{4}\right)^{4)}$, 井上ら ${ }^{5)}$, 野田 ${ }^{6)}$, 佐藤 $5^{7)}$ は, 気象庁一倍強震計や87型強震計の記録 をもとに，フーリエスペクトル4), 速度応答スペク トル (5)-7)を指標とした距離減衰式を求め, やや長周 
表-1 距離減衰式の作成に用いた地震のリスト

\begin{tabular}{|c|c|c|c|c|c|c|c|}
\hline No. & 発生年月日 & 震源地または地震名 & $M_{J}$ & $M_{w}$ & 深さ $[\mathrm{km}]$ & タイプ & 断層モデル \\
\hline 1 & 1964.6 .16 & 新潟地震 & 7.5 & 7.6 & 34 & 海溝 & 9) \\
\hline 2 & 1968.4 .1 & 日 向灘地震 & 7.5 & 7.4 & 30 & 海溝 & 9) \\
\hline 3 & 1993.7 .12 & 北海道南西沖地震 & 7.8 & 7.6 & 35 & 海溝 & 10) \\
\hline 4 & 1994.10 .4 & 北海道東方沖地震 & 8.2 & 8.2 & 28 & 海溝 & 11) \\
\hline 5 & 1994.10 .9 & 北海道東方沖（余震） & 7.3 & 7.2 & 0 & 海溝 & - \\
\hline 6 & 1994.12 .28 & 三陸はるか沖地震 & 7.6 & 7.7 & 0 & 海溝 & 12) \\
\hline 7 & 1995.1 .7 & 岩手県北東沖 & 7.2 & 6.9 & 48 & 海溝 & - \\
\hline 8 & 1995.1 .17 & 兵庫県南部地震 & 7.3 & 6.9 & 16 & 内陸 & 13) \\
\hline 9 & 1995.12 .4 & 択捉島南東沖 & 7.3 & 7.7 & 57 & 海溝 & 14) \\
\hline 10 & 1996.8 .11 & 秋田県南部 & 6.1 & 5.9 & 9 & 内陸 & - \\
\hline 11 & 1997.3.26 & 鹿児島県北西部 & 6.6 & 6.0 & 12 & 内陸 & 15) \\
\hline 12 & 1997.5 .13 & 鹿児島県北西部 & 6.4 & 6.0 & 9 & 内陸 & 15) \\
\hline 13 & 1997.6 .25 & 山口県北部 & 6.6 & 5.8 & 8 & 内陸 & 16) \\
\hline 14 & 1998.9 .3 & 岩手県北部 & 6.2 & 5.9 & 8 & 内陸 & 17) \\
\hline 15 & 2000.1 .28 & 根室半島沖 & 7.0 & 6.7 & 59 & 海溝 & - \\
\hline 16 & 2000.10 .6 & 鳥取県西部地震 & 7.3 & 6.7 & 9 & 内陸 & 18) \\
\hline 17 & 2003.7 .26 & 宮城県北部 & 6.4 & 6.1 & 12 & 内陸 & 19) \\
\hline 18 & 2003.9 .26 & 十勝沖地震 & 8.0 & 8.2 & 42 & 海溝 & 20) \\
\hline 19 & 2003.9 .26 & 十勝沖（余震） & 7.1 & 7.3 & 21 & 海溝 & - \\
\hline 20 & 2004.9 .5 & 東海道沖 & 7.4 & 7.4 & 44 & 海溝 & 21) \\
\hline 21 & 2004.10 .23 & 新潟県中越地震 & 6.8 & 6.6 & 13 & 内陸 & 22) \\
\hline 22 & 2004.10 .23 & 新潟県中越（余震） & 6.5 & 6.3 & 14 & 内陸 & 22) \\
\hline 23 & 2004.11 .29 & 釧路沖 & 7.1 & 7.0 & 48 & 海溝 & 23) \\
\hline 24 & 2005.3 .20 & 福岡県西方沖 & 7.0 & 6.6 & 9 & 内陸 & 24) \\
\hline 25 & 2005.8 .16 & 宮城県沖 & 7.2 & 7.2 & 42 & 海溝 & 25) \\
\hline
\end{tabular}

期地震動の摇れやすさを観測点ごと，周期ごとに評 価している。また座間ら ${ }^{8}$ は観測記録から直接導い た距離減衰式ではなく，地震規模と立ち上がり時間, 断層長さ等の経験式を理論加速度スペクトルに導入 した標準スペクトルモデルを作成し，それと観測ス ペクトルとのずれから観測点の摇れやすさの周期特 性を評価している.

上記の研究で摇れや寸さが周期特性も含めて評価 されているのは最大でも39地点)であり, 日本全国 でやや長周期地震動の摇れや寸さが周期ごとに明ら かになっている状況ではない，そこで本研究では, 島嶼部を除き全国をほぼ網羅する1775観測点で得ら れた既往の観測記録をもとに，周期 $2 \sim 20$ 秒のやや 長周期地震動を対象とした加速度応答スペクトル

（減衰定数 $1 \%, 5 \%$ ）および加速度フーリエスペクト ルを推定するための距離減衰式を作成した。 また, 距離減衰式を作成する際の回帰分析で得られる観測
点補正值をもとに, 全国における地点補正倍率を算 定した。

この地点補正倍率を用いることにより，任意の地 点における地震動増幅特性を考慮したやや長周期地 震動の地震動強さを推定することができる. その事 例として, 南海地震および東海・東南海・南海連動 地震のやや長周期地震動を試算し, 妥当性と有効性 を検討した。

\section{2. データ}

距離減衰式の作成には，日本及びその周辺で発生 した1964年6月～2005年8月の地震により得られた観 測記録を用いた。やや長周期地震動を励起しや寸い 地震を対象とするために, 内陸地震は気象庁マグニ チュード $M_{J} 6.0$ 以上, 海溝性地震は $M_{J} 7.0$ 以上の地 
表-2 距離減衰式の作成に用いた地震，観測点，記録の数

\begin{tabular}{ccc}
\hline & 海溝性地震 & 内陸地震 \\
\hline 地震数 & 14 & 11 \\
\hline 観測点数 & 1311 & 1086 \\
\hline 記録数 & 2374 & 1880 \\
\hline
\end{tabular}

震を選択し，データが少ない，あるいは観測点の特 性などからデータに偏りがあると見られるものは除 外した。最終的に解析対象とした地震のリス卜を 表-1に示す. 表中の深さは気象庁による震源深さ, タイプは海溝性地震（海溝）と内陸地震（内陸）に 分類した場合の地震タイプ, 断層モデルは後述の距 離の算出に断層モデルを用いた場合の参考文献を示 している. 日本海東縁部で発生する地震は直接海溝 と結びつけられないが，ここでは海域で発生した 1964新潟地震と1993年北海道南西沖地震を海溝性地 震に分類した。海溝性地震はモーメントマグニチュ ード $M_{w} 6.7 \sim 8.2$ の 14 地震, 内陸地震は $M_{w} 5.8 \sim 6.9$ の 11地震が対象となっている.

1995年兵庫県南部地震より前の観測記録は, 全て 気象庁の一倍強震計または87型強震計によるもので ある。一倍強震計の観測記録としては，建設省土木 研究所が数值化し計器補正を施した波形データ 26), 27) を用いる．この波形データは，一倍強震計の記録精 度がある程度保証されている, 周期 $2 \sim 20$ 秒の周期 帯 $^{28)}$ のバンドパスフィルターを施したものであるた め, 気象庁87型, 95型強震計やその他の機関の観測 により得られた記録にも, 同様のバンドパスフィル ターを施した。 したがって，ここでは周期 $2 〜 20$ 秒 のやや長周期地震動が対象となる。この周期帯域の 地震動に対する観測精度が確保されていると考えら れる記録を収集し，目視で記録長が不十分とみられ るものを除去した後, 前処理として各波形データの 平均值を除去するオフセット除去と波形の目視で判 別したスパイクノイズの除去を実施した.

これらの条件により選択および処理されたデータ を海溝性地震と内陸地震に分類したデータセットを 作成し, それぞれについて距離減衰式を作成した。

表-2に地震タイプ別の地震数と観測点数および記録 数（水平 2 成分で 1 記録）を示寸. 海溝性地震と内陸 地震で共通の観測点が622点あるため, 観測点の総 数は1775点である.これら観測点の位置を表-1の地 震の震央とともに図-1に示す. 地震の番号は表-1と 図-1で共通である。

距離減衰式の作成に用いる観測記録を選択する際, 強震計のトリガーレベルの影響を考慮して, 震源域

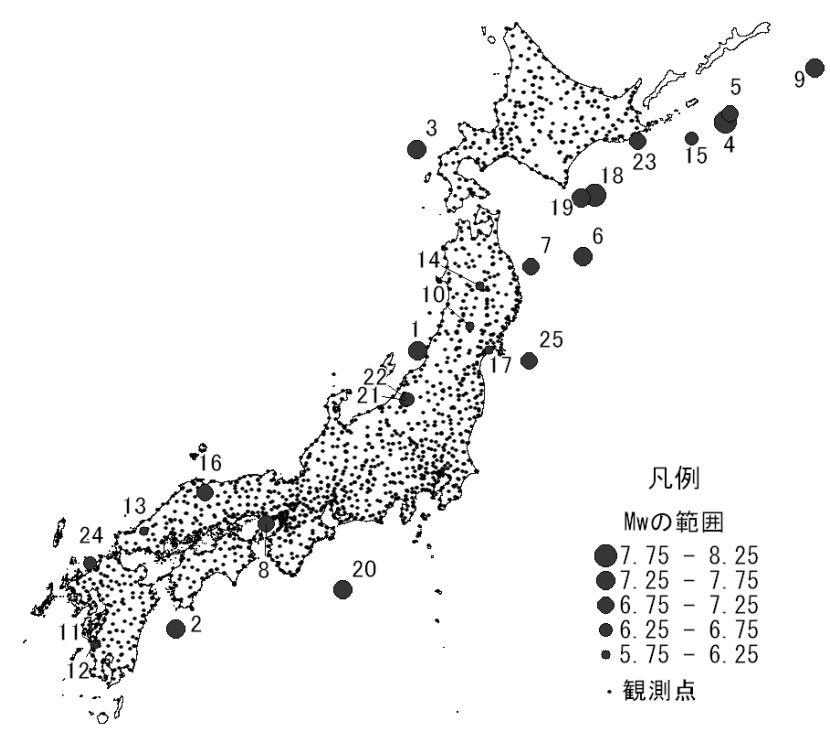

図-1＼cjkstart回帰分析に用いた記録の観測点と地震の震央

からの距離が一定值を越えない観測記録のみを選択 することが行われる ${ }^{29)}$. 本研究では, トリガーレ ベルを規定する短周期の地震動を対象としていない ことに加えて, 後述のように観測点ごとの地震動増 幅特性を表す観測点補正值が算出される回帰分析を 行うため, トリガーレベルの影響を考慮した観測記 録の選択は行っていない. なお, 2003 年十勝沖地 震の観測記録を用いて, 断層面最短距離が $300[\mathrm{~km}]$

(距離減衰式 ${ }^{30}$ ) で最大加速度が $10\left[\mathrm{~cm} / \mathrm{s}^{2}\right]$ と推定さ れる距離）を越える観測点で得られた観測記録を含 めた場合と除いた場合で, 得られる回帰係数（後述 の $b$ と $d)$ に大きな差がないことを確認している.

\section{3. 距離減衰式の作成}

\section{（1）地震動強さの指標}

2. で記述したデータセットから加速度応答スペ クトルおよび加速度フーリエスペクトルを計算し, それらを地震動強さの指標とした距離減衰式を作 成した。

加速度応答スペクトルは，水平 2 成分それぞれ の観測記録に対する一自由度系 (固有周期 $T_{n}$, 減 衰定数 $1 \%$ および $5 \%$ ）の加速度応答波形を計算し, この応答波形の水平 2 成分合成の最大值をとった ものを $S_{A}\left(T_{n}\right)\left[\mathrm{cm} / \mathrm{s}^{2}\right]$ として固有周期 $T_{n}=2 \sim 20[\mathrm{~s}]$ の範囲を $1[\mathrm{~s}]$ 刻みで計算した。気象庁一倍強震計 の一部の記録については, 明らかに NS 成分と EW 成分の $\mathrm{S}$ 波初動時刻に差異が見られたため, $\mathrm{S}$ 波 初動時刻が同一になるように, 一方の記録をシフ トして 2 成分を合成した。 なお, 相対速度応答ス 


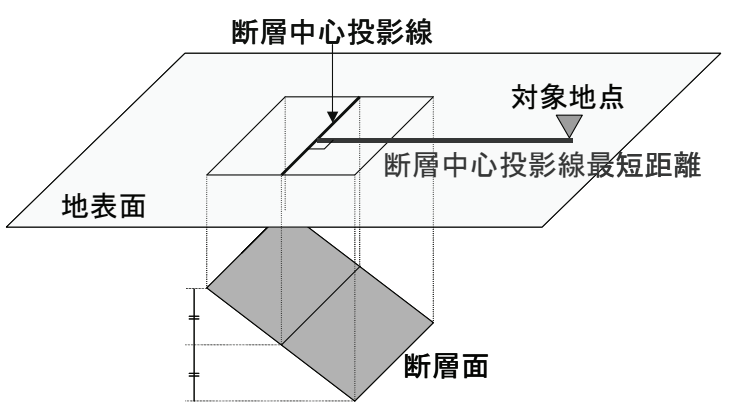

図-2 断層中心投影線最短距離の定義

ペクトルを用いると，長周期帯域の值が入力波の 最大速度に漸近するために, 長周期帯域の地震動 特性が十分に反映されない可能性があるが，加速 度応答スペクトルの場合にはそのような問題は生 じない ${ }^{7)}$.

加速度フーリエスペクトル $F_{A}(T)\left[\mathrm{cm} / \mathrm{s}^{2} ・ \mathrm{~s}\right]$ はバ ンド幅 $0.02[\mathrm{~Hz}]$ の Parzen ウィンドウで平滑化した 水平 2 成分の加速度フーリエスペクトルの算術平 均とし, 同様に周期 $T=2 \sim 20[\mathrm{~s}]$ の範囲を $1[\mathrm{~s}]$ 刻み で計算した。

\section{（2）震源域からの距離の指標}

ここで対象としている 2〜20[s]の周期帯では, 実体波よりも表面波が優勢と考え，表面波は水平 方向に伝播することから，水平距離を距離の指標 とする。ただし, 東南海・南海地震など, 震源域 が大きく広がる地震も対象となることから，震央 距離ではなく，図-2 に示す断層中心投影線最短距 離を震源域からの距離の指標として用いることに した. 図-3 に強震記録が得られた地震のモーメン トマグニチュード $M_{w}$ と断層中心投影最短距離 $X$ $[\mathrm{km}]$ との関係を示す。ここで，X は表-1 に断層モ デルの参考文献が示されている地震についてはそ の断層中心投影線からの最短距離, その他の地震 は気象庁発表の震央からの距離である。

\section{（3）回帰モデル}

同じ規模の地震でも震源が浅いほど表面波が励 起されやすいため, 震源深さをパラメータとする ことにより推定精度が向上する可能性がある。そ こで，(1)で述べた指標を式(1)と(2)でモデル化し， 震源深さ（表-1 に断層モデルの参考文献が示され ている地震についてはその断層中心深さ） $D[\mathrm{~km}]$ をパラメータとしない場合とする場合について， ダミ一係数を用いた二段階回帰分析手法 29), 7), 30)で 回帰分析を行った。以下では地震動強さの指標を $Y$ で代表させる.

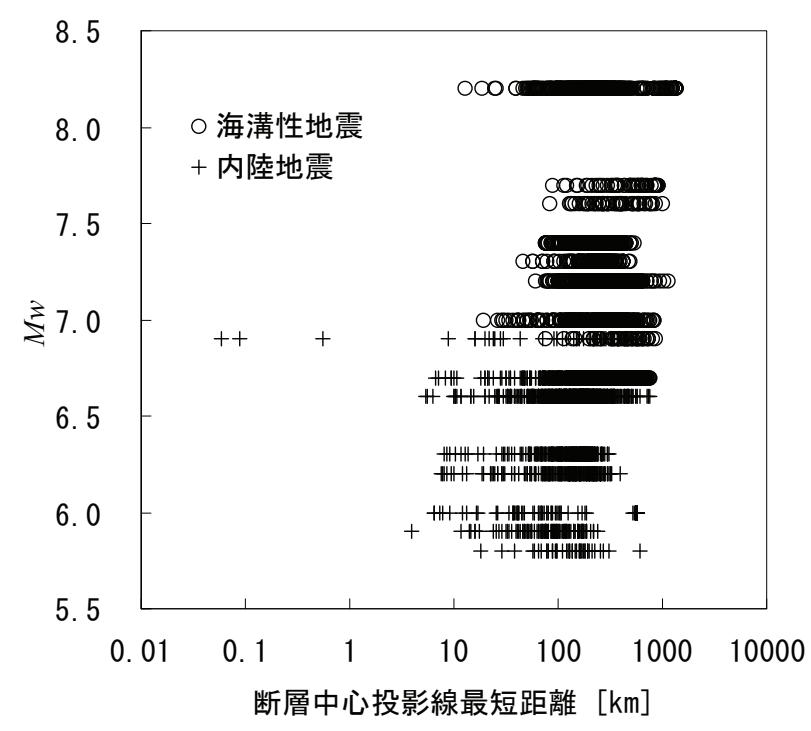

図-3 記録の $M_{w}$ と断層中心投影線最短距離との関係

$$
\begin{aligned}
\log _{10} Y_{i j}= & a_{1} M_{w}-b X_{i j}+c_{0} \\
& -d \log _{10}\left(X_{i j}+p \cdot 10^{q M_{w}}\right)+c_{j} \pm e \\
\log _{10} Y_{i j}= & a_{1} M_{w}+a_{2} D-b X_{i j}+c_{0} \\
& -d \log _{10}\left(X_{i j}+p \cdot 10^{q M_{w}}\right)+c_{j} \pm e
\end{aligned}
$$

ここで， $X$ は断層中心投影線最短距離 $[\mathrm{km}], \quad Y_{i j}$ は $i$ 番目の地震の $j$ 番目の観測点における地震動強さ, $c_{j}$ は $j$ 番目の観測点の観測点補正值， $e$ は誤差であ る. 回帰係数 $a_{1}, a_{2}, b, c_{0}, c_{j}, d, p$ は, 固有周期 $T_{n}$ または周期 $T$ ごとに求められる. 係数 $q$ は全固 有周期または周期で同一とした。

幾何減衰項中の $p \cdot 10^{q M_{w}}$ は，震源近傍における 地震動強さの頭打ちを表す量であり，ここでは飽 和距離とよぶ。また観測点補正值 $c_{j}$ は, 距離減衰 式の推定值を観測点ごとの地震動増幅特性に応じ て補正するための係数である.

\section{（4）回帰分析の手順}

回帰分析は以下の手順で，海溝性地震と内陸地 震それぞれに対して，対象とする指標および周期 ごとに実施した。震源深さをパラメータとしない 場合の回帰係数が b) で，震源深さをパラメータと する場合の回帰係数がc)で求められる.

\section{a）飽和距離がないモデルを用いた回帰分析}

まず，飽和距離を考慮しない式(3)のモデルを用 いて二段階回帰分析により各係数を決定した。

$$
\log _{10} Y_{i j}=a_{1} M_{w}-b X_{i j}+c_{0}-d \log _{10} X_{i j}+c_{j}
$$

一段階目の回帰分析では，地震動強さの指標を 式(4)でモデル化し, 式(6)中の係数 $S_{i}, b, c_{1 j}, d$ を式 (5)の地震内誤差 $e_{I N T R A}$ が最小となるように決定し 
た。この際，拘束条件が必要になるため，周期 $0.25[\mathrm{~s}]$ 以上ではサイト特性がないと考えられてい る K-NET の IWT009 (大東) を基準観測点として, 地点補正值 $c_{1 j}=0$ とした ${ }^{31), 30)}$. 係数 $d$ は加速度フ ーリエスペクトルの場合は表面波の幾何減衰を表 す 0.5 , 加速度応答スペクトルの場合は表面波の分 散性による見かけの減衰 ${ }^{32)}$ を考慮するために 0.5 〜 1.0 の範囲でグリッドサーチにより最適值を求め た.

$$
\begin{gathered}
\log _{10} Y_{i j}=a_{1} M_{w}-b X_{i j}-d \log _{10} X_{i j}+c_{1 j} \pm e_{I N T R A} \\
e_{\text {INTRA }}=\sqrt{\sum_{i=1}^{I} \sum_{j=1}^{J} \delta_{i j} R_{i j}^{2} / \sum_{i=1}^{I} \sum_{j=1}^{J} \delta_{i j}} \\
R_{i j}=\log _{10} Y_{i j}-S_{i}+d \log _{10} X_{i j}+b X_{i j}-c_{1 j}
\end{gathered}
$$

ここで， $\delta_{i j}$ は $i(i=1,2, \cdots, I)$ 番目の地震の強震記 録が $j(j=1,2, \cdots, J)$ 番目の観測点に存在する場合 に 1 , 存在しない場合は 0 である.

二段階目の回帰分析では，一段階目で得られた $b, d$ を用いて重相関解析により式(7)の係数 $a_{1}, c_{2 j}$ を 決定した。

$$
\log _{10} Y_{i j}+d \log _{10} X_{i j}+b X_{i j}=a_{1} M_{w}+c_{2 j} \pm e_{T O T A L}
$$

ここで， $e_{T O T A L}$ は全体誤差である. 式(7)の左辺と しては，一段階目の回帰分析で得られた $S_{i}$ を用い ることもできるが， $b$ と $d$ を与えた条件下でデー タセットに最適な $a_{1}$ と観測点補正值を得るために, この式形を用いている.

以上の結果をもとに，式(3)の係数 $c_{0}$ と観測点補 正值 $c_{j}$ を，全観測点での $c_{j}$ の平均が 0 となるよう に次式で定めた.

$$
c_{0}=\frac{1}{J} \sum_{j=1}^{J} c_{2 j} \quad, \quad c_{j}=c_{2 j}-c_{0}
$$

\section{b）飽和距離があるモデルを用いた回帰分析}

上記 a) で得られた係数 $a_{1}, b, c_{0}, c_{j}, d$ を用い て, 飽和距離を考慮した式(1)の係数 $p, q$ を求めた。 ここでは震源近傍の記録が含まれる 2003 年十勝沖 地震と全ての内陸地震のデータを使用した.

係数 $p$ は周期ごとに 0 ～ 0.002 の範囲で，係数 $q$ は全周期同一として加速度応答スペクトルの場合 $0.5 \sim 1.2$, 加速度フーリエスペクトルの場合 0.5 ～ 1.4 の範囲で，グリッドサーチにより全体誤差 $e_{\text {TOTAL }}$ が最小となる值を求めた. グリッドサーチの 範囲は既存の距離減衰式を参考に定めた。

この結果を式(1)に代入し，再度 a) と同様の手順
により係数 $a_{1}, b, c_{0}, c_{j}, d$ を求めた. 寸なわち, 一 段階目の回帰分析では，地震動強さの指標を式(9) でモデル化し, 式(11)中の係数 $S_{i}, b, c_{1 j}, d$ を式(10) の地震内誤差 $e_{I N T R A}$ が最小となるように決定した。

$$
\begin{aligned}
\log _{10} Y_{i j}= & a_{1} M_{w}-b X_{i j} \\
- & d \log _{10}\left(X_{i j}+p \cdot 10^{q M_{w}}\right)+c_{1 j} \pm e_{I N T R A} \\
e_{I N T R A}= & \sqrt{\sum_{i=1}^{I} \sum_{j=1}^{J} \delta_{i j} R_{i j}^{2} / \sum_{i=1}^{I} \sum_{j=1}^{J} \delta_{i j}} \\
R_{i j}= & \log _{10} Y_{i j}-S_{i} \\
+ & d \log _{10}\left(X_{i j}+p \cdot 10^{q M_{w}}\right)+b X_{i j}-c_{1 j}
\end{aligned}
$$

次に，二段階目の回帰分析では，一段階目で得 られた $b, d$ を用いて重相関解析により式(12)の係 数 $a_{1}, c_{2 j}$ を決定した.

$$
\begin{aligned}
& \log _{10} Y_{i j}+d \log _{10}\left(X_{i j}+p \cdot 10^{q M_{w}}\right)+b X_{i j} \\
& \quad=a_{1} M_{w}+c_{2 j} \pm e_{\text {TOTAL }}
\end{aligned}
$$

以上の結果をもとに，式(1)の係数 $c_{0}$ と観測点補 正值 $c_{j}$ を, 全観測点での $c_{j}$ の平均が 0 となるよう に式(8)で定めた.

この場合の地震間誤差 $e_{I N T E R}$ は, 式(9)の $e_{I N T R A}$ と 式(12)の $e_{T O T A L}$ から次式で計算できる.

$$
e_{\text {TOTAL }}=\sqrt{e_{\text {INTRA }}^{2}+e_{\text {INTER }}^{2}}
$$

\section{c）震源深さをパラメータとした場合の回帰分析}

上記 b)の一段階目で得られた $b, d$ を用い，二段 階目の回帰分析として, 式(14)の係数 $a_{1}, a_{2}, c_{2 j}$ を 重相関解析により決定した.

$$
\begin{gathered}
\log _{10} Y_{i j}+d \log _{10}\left(X_{i j}+p \cdot 10^{q M_{w}}\right)+b X_{i j} \\
=a_{1} M_{w}+a_{2} D+c_{2 j} \pm e_{\text {TOTAL }}
\end{gathered}
$$

この場合の地震間誤差 $e_{I N T E R}$ は，式(9)の $e_{I N T R A}$ と 式(14)の $e_{T O T A L}$ から式(13)で計算できる.

以上の結果をもとに，式(2)の係数 $c_{0}$ と観測点補 正值 $c_{j}$ を, 全観測点での $c_{j}$ の平均が 0 となるよう に式(8)で定めた.

\section{4. 作成した距離減衰式の特徵}

本研究では前述の通り，3種類の地震動強さを指 標としているが，得られた結果はほぼ同じ傾向にあ るため, 以下では減衰定数 $1 \%$ の加速度応答スペク トルを指標とした場合を中心に記述する。 


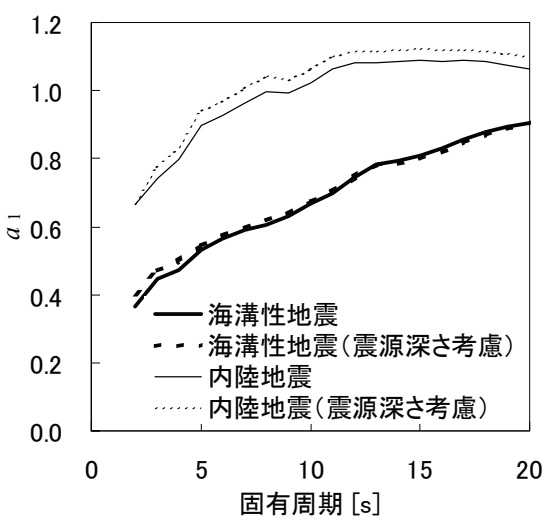

(a) 係数 $a_{1}$

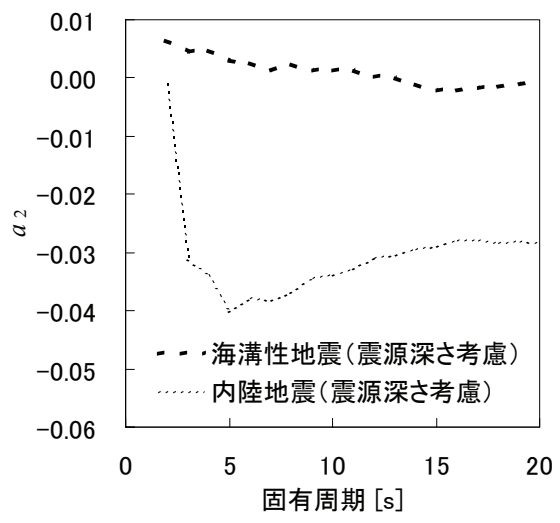

(b) 係数 $a_{2}$

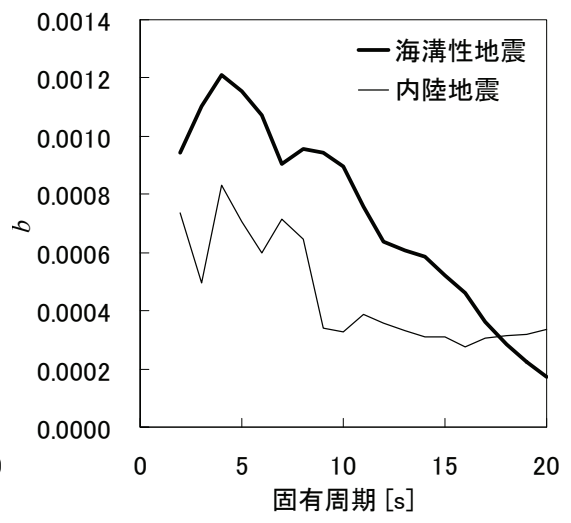

(c) 係数 $b$

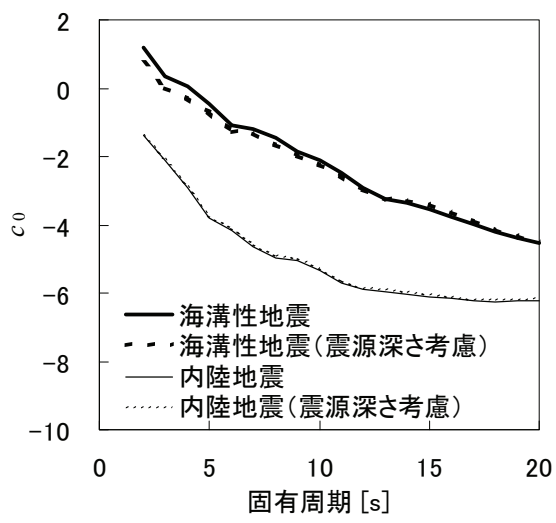

(d) 係数 $c_{0}$

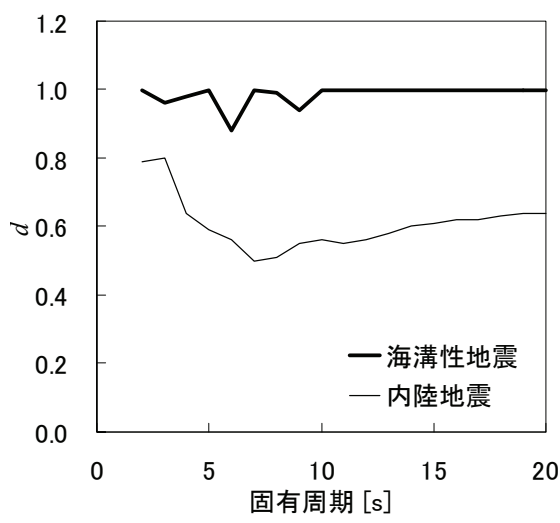

(e) 係数 $d$

図-4 加速度応答スペクトル（減衰定数 $1 \%$ ）の距離減衰式の回帰係数

\section{(1) 回帰係数}

減衰定数 $1 \%$ の加速度応答スペクトルの場合を例 として, 作成した距離減衰式の回帰係数のうち $a_{1}$, $a_{2}, b, c_{0}, d$ を図-4に示す.

マグニチュード依存性を表す係数 $a_{1}$ についてみる と, 内陸地震の方が海溝性地震よりも大きく, 短周 期の地震動が支配的な最大加速度, 最大速度, 計測 震度といった指標の距離減衰式と同様の傾向を示し ている30)が，長周期の方がその違いが顕著である. これは，地震規模が大きくなるにつれて断層面が大 きくなり, 内陸地震では震源深さにかかわらず地殼 内のごく浅い領域でもずれが発生することで，表面 波を励起しやすくなることが一因と考えられる.

海溝性地震の場合, 震源深さをパラメータとする か否かでは $a_{1}$ にあり大きな違いはなく，そのこと が $a_{2}$ の大きさにも表れている. 一方, 内陸地震の場 合， $a_{2}$ は固有周期 $2[\mathrm{~s}]$ の場合を除いて $-0.03 \sim-0.04$ 程 度となっており, 震源が浅いほど表面波が強く励起 され, やや長周期地震動の振幅が大きくなる傾向を 表している．ただし上述の通り，この影響の一部は 内陸地震の $a_{1}$ の大きさに現れていると考えられる. 海溝性地震の場合にこのような傾向が現れない理由 は不明であるが, 海溝性地震の観測記録には震源域 からの距離が遠いものが多く（図-3），伝播経路が
複雑であることが関係している可能性がある.

二段階回帰分析の一段階目で計算される $b$ と $d$ は, 震源深さをパラメータとするか否かでは変わらない. 一方, $b$ と $d$ は海溝性地震と内陸地震ではかなり異 なり, どちらも全般に海溝性地震の方が大きい. 距 離減衰特性を表すこれらの係数は本来, 地震のタイ プの影響を受けない性質のものであるため, この違 いは地震のタイプによる発生位置の偏りを反映した ものと考えられる ${ }^{30)}$. 海溝性地震の $d$ は幾何減衰と 分散性による減衰の和の上限值として設定した $1.0^{32)}$ となる固有周期が多く, 分散性による減衰の 影響が大きいことが分かる.

\section{（2）距離減衰式のばらつき}

3. (4) の回帰分析において得られた地震内誤差 $e_{\text {INTRA }}$ と地震間誤差 $e_{I N T E R}$ を図-5に示す. 図-5(a)の地 震内誤差 $e_{\text {INTRA }}$ は, 震源深さをパラメータとしない 場合とした場合で同一であり, 海溝性地震と内陸地 震の場合でも同程度の大きさとなっている.

図-6 に観測点ごとに用いた観測記録数の頻度分 布を示すが，1 つの地震の記録しか使用していな い観測点が海溝性地震で 822 点, 内陸地震で 523 点存在する.これらの観測点では, 観測点補正值 がそのデータのみで決定されるため, 観測点補正 


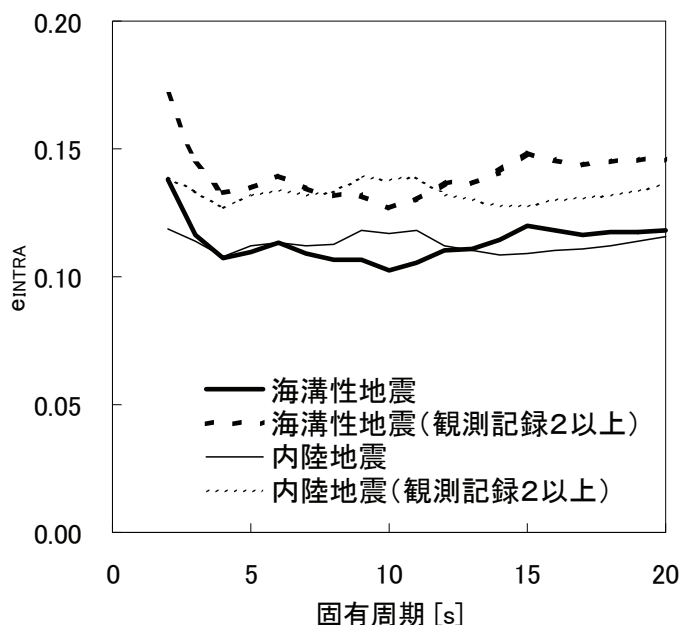

(a) 地震内䛊差

図-5 加速度応答スペクトル

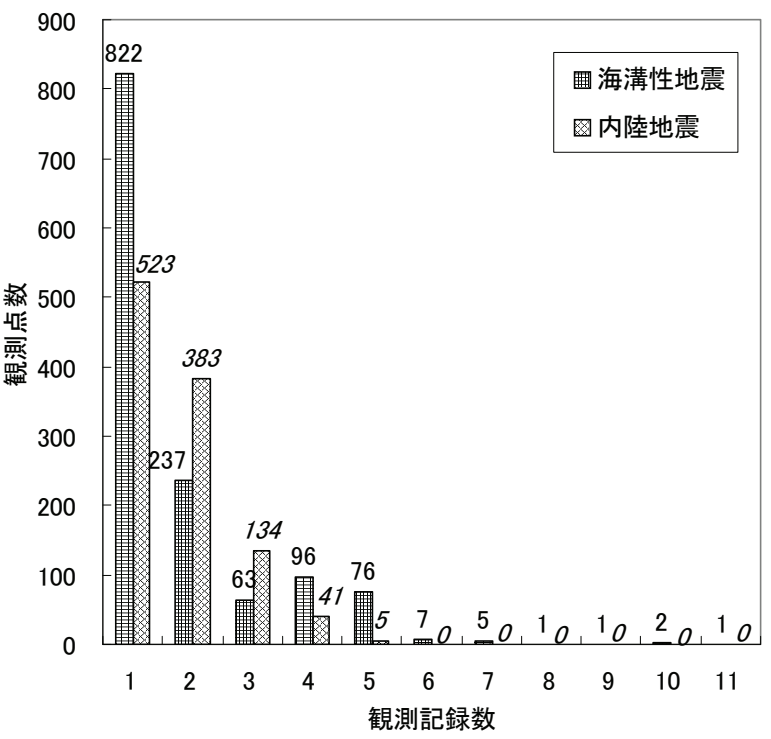

図-6 観測点ごとに用いた観測記録数の頻度分布

值を考慮した距離減衰式による予測值とデータが 等しくなる ${ }^{30)}$ 。そのため, 図-5 の地震内誤差は過 小評価になっている可能性がある，観測記録を 2 つ以上使用している観測点のデータのみ用いた場 合，地震内誤差の分布は対数正規分布でよく近似 され ${ }^{30)}$, これが地震内誤差をより正確に評価した ものと考えられることから，その標準偏差も図一 5 (a)に示してある。これらはもともとの地震内誤 差よりも 0.03 程度大きいが，観測点ごとの地震動 増幅特性の違いによる誤差が含まれていない ${ }^{30)} た$ め，比較的小さい值となっている.

図-5(b) の地震間誤差 $e_{\text {INTER }}$ は, 震源深さをパラメ ータとしない場合とした場合で異なり，震源深さを パラメータとした方が小さいが，海溝性地震ではそ の違いはごくわずかである。一方，内陸地震では 0.04 程度小さくなっている周期が多く, 震源深さに よる地震動強さの違いを考慮することで，推定精度

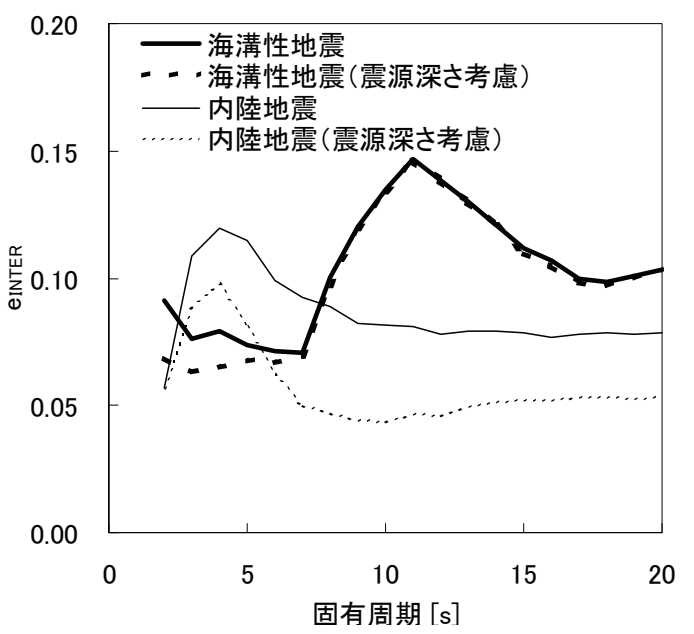

(b) 地震間誤差

（減衰定数 1\%）の距離減衰式の誤差

が改善されていることを示している。これらは海溝 性地震と内陸地震で $a_{2}$ の大きさが異なる（図-4） ことに対応している.

なお，本研究で作成した距離減衰式の回帰係数と 回帰誤差は付録の表に示す．海溝性地震では震源深 さの影響が小さいこと，また内陸地震ではやや長周 期地震動が問題になる規模の地震では断層中心深さ に差が生じないと考えられるため, 震源深さをパラ メータとしない場合の回帰係数を示寸.

\section{（3）推定される地震動強さと既往の研究との比較}

作成した距離減衰式から推定される加速度応答又 ペクトルを，佐々木らの周期 2〜20[s]の地震動を対 象とした距離減衰式 ${ }^{33)}$ から推定したものと比較する。 佐々木らの距離減衰式は, $5 つ の$ 海溝性地震 $\left(M_{w}\right.$ 7.4〜8.2) から得られた気象庁一倍強震計の記録に 基づくものであり，次式のモデルが用いられている．

$$
S_{A}\left(T_{n}, h\right)=a\left(T_{n}, h\right) \cdot 10^{b\left(T_{n}, h\right) \cdot M_{J}} \cdot(\Delta+30)^{c\left(T_{n}, h\right)}
$$

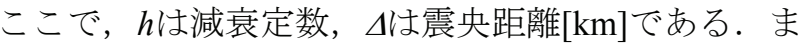
た， $a, b, c$ は回帰係数であり, 重回帰分析により求 められている. 回帰係数は，データを観測点の摇れ

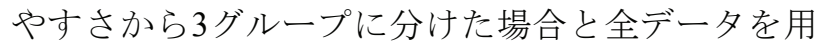
いた場合を合わせた4ケースそれぞれについて，減 衰定数 $2 \%$ と $5 \%$ の加速度応答スペクトル（水平 2 成 分のうち大きい方）を指標とした，計8ケースにつ いて求められている.

ここでは本研究と比較できるケースとして，全デ 一タ 97 成分を用い減衰定数を $5 \%$ とした距離減衰式 で推定した加速度応答スペクトルを図-7に示す。た だし, $M_{w}=M_{J}, X=\Delta$ とし, 比較のため本研究の距 離減衰式は震源深さをパラメータとしない場合の式 とする．内陸地震については，記録を用いた地震の 


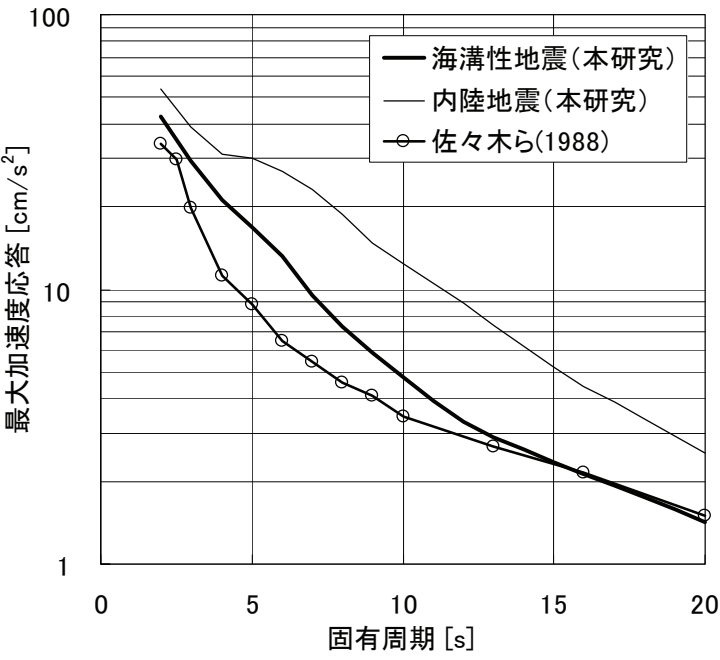

(a) $M_{w}=M_{J}=7.5, X=\Delta=100[\mathrm{~km}]$

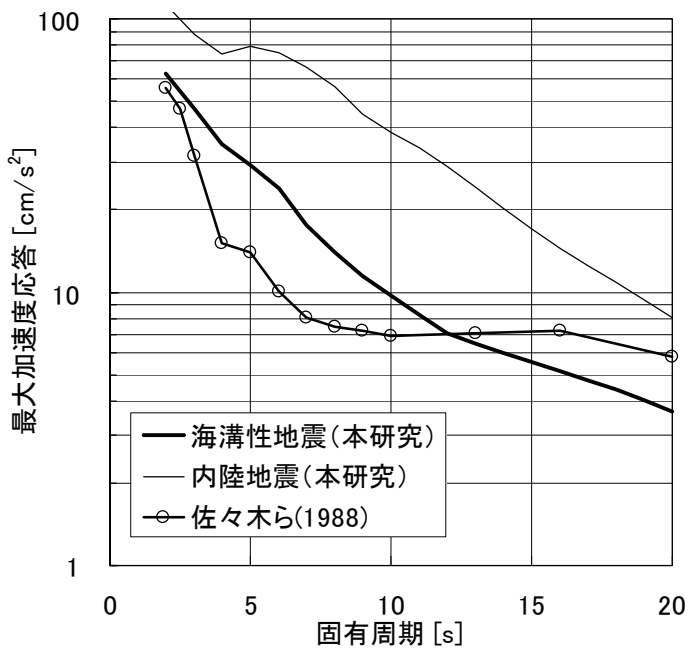

(b) $M_{w}=M_{J}=8.0, X=\Delta=100[\mathrm{~km}]$

図-7 距離減衰式により推定した加速度応答スペクトル（減衰定数 5\%）の比較

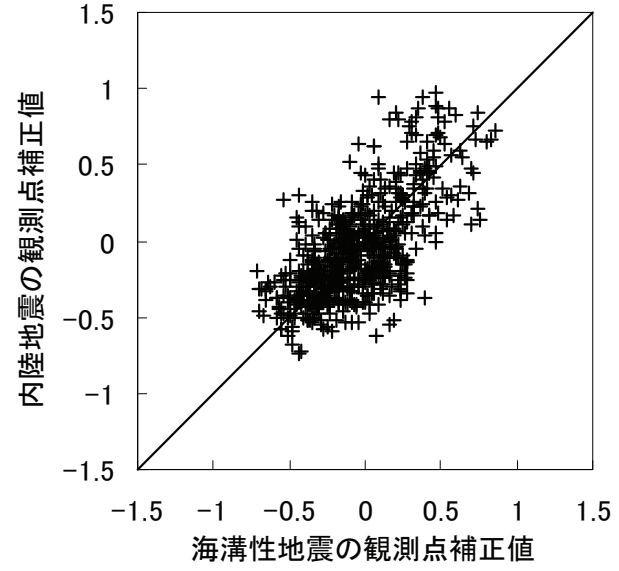

図-8 加速度応答スペクトル值 $\left(T_{n}=7[\mathrm{~s}]\right.$, 減衰定数 $\left.1 \%\right)$ の観測点補正值の比較

規模の範囲外であり，また規模の大きい地震では $M_{w}$ と $M_{J}$ が異なる場合が多いが，参考に示している この図によると，海溝性地震の記録に基づく佐々木 らの距離減衰式は，記録数を考慮すれば，本研究の 同じく海溝性地震の記録に基づく式に近い推定結果 を与えるものとなっている。

また外挿による推定結果ではあるが，本研究の距 離減衰式では, $M_{w} 7.5$ の内陸地震と $M_{w} 8.0$ の海溝性 地震では $X=100[\mathrm{~km}]$ で同程度の加速度応答スペクト ルが推定されている。したがって，規模が非常に大 きい内陸地震が発生した場合には，震源域近傍にお ける短周期の地震動には当然注意が必要であるが, やや長周期地震動についても海溝性巨大地震と同様, 影響が広い範囲に及ぶ可能性がある。

\section{（4）観測点補正倍率}

海溝性地震と内陸地震の両方で記録が得られてい
る観測点622点については，海溝性地震と内陸地震 それぞれの距離減衰式に対する観測点補正值が得ら れている。これらを比較した例が図-8であるが，あ る程度の違いが見られる。ここでは次式のように記 録数に応じた重みを付けた上で，その観測点の観測 点補正值 $c_{j}$ を求めた.

$$
c_{j}=\frac{n^{(s)} c_{j}^{(s)}+n^{(l)} c_{j}^{(l)}}{n^{(s)}+n^{(l)}}
$$

ここで， $n^{(s)}$ と $n^{(l)}$ はそれぞれ海溝性地震と内陸地震 の回帰分析で使用した $j$ 番目の観測点の記録数, $c_{j}^{(s)}$ と $c_{j}^{(l)}$ はそれぞれ海溝性地震と内陸地震の回帰分 析で得られた $j$ 番目の観測点の観測点補正值である。

次に，観測点補正倍率 $s_{j}$ を次式で定義した.

$$
s_{j}=10^{c_{j}}
$$

したがって,$c_{j}=0$ とした距離減衰式から推定さ れる加速度応答スペクトル $S_{A}\left(T_{n}\right)$ あるいは加速度フ ーリエスペクトル $F_{A}(T)$ に観測点補正倍率 $s_{j}$ を乗じ ることにより, その地点周辺の地盤による地震動増 幅特性を考慮した地震動強さが推定できる。観測点 補正值 $c_{j}=0$ とした距離減衰式から推定される地震 動強さは，全観測点の平均的な地震動増幅特性を考 慮したものであるから，観測点補正倍率 $s_{j}$ は，そ の観測点が平均的な地盤条件と比較して，着目する 周期の地震動を何倍に増幅させるかを表したものと 言い換えてもよい.

減衰定数 $1 \%$ の加速度応答スペクトル $\left(T_{n}=3,7,10\right.$, 15 [s]）の場合を例として，距離減衰式に対する観 測点補正倍率の分布を示したのが図-9である。この 図に示した全1775観測点の観測点補正倍率の分布を 


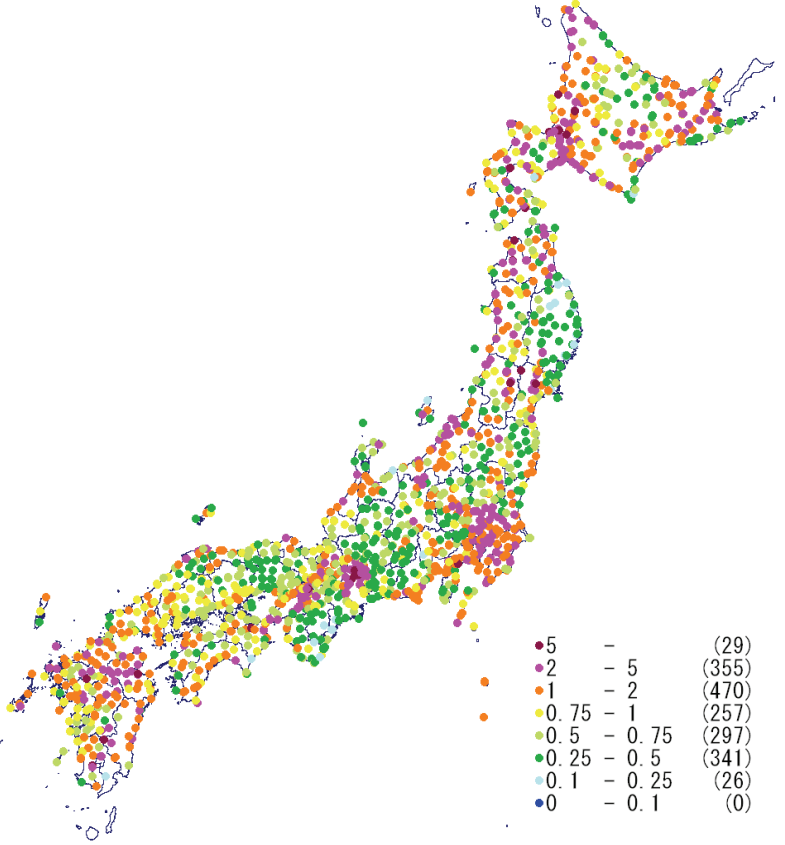

(a) $T_{n}=3[\mathrm{~s}]$

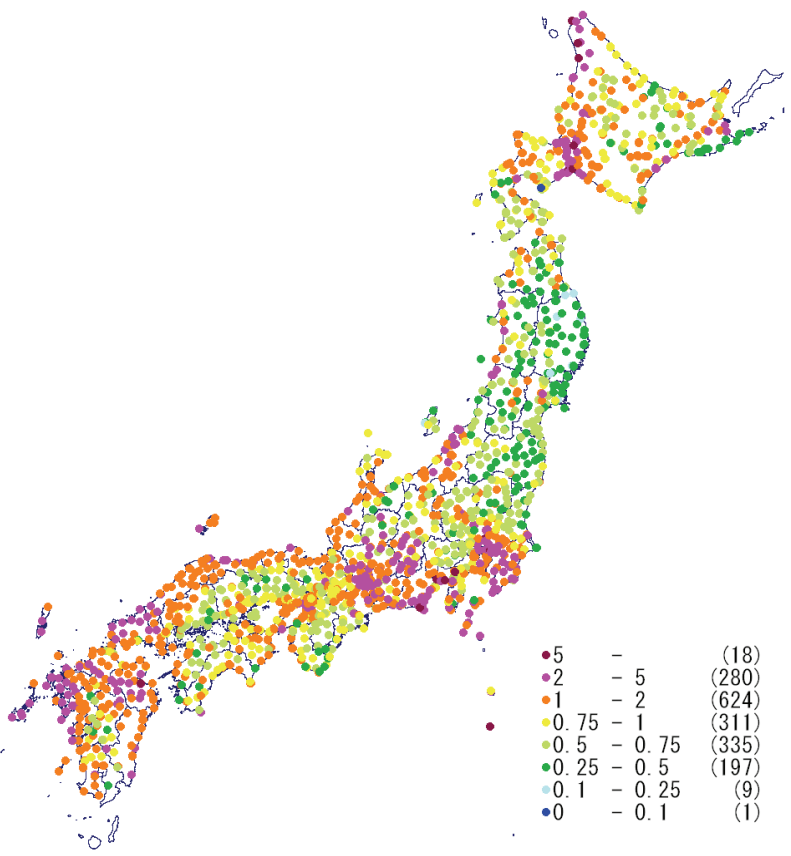

(c) $T_{n}=10[\mathrm{~s}]$

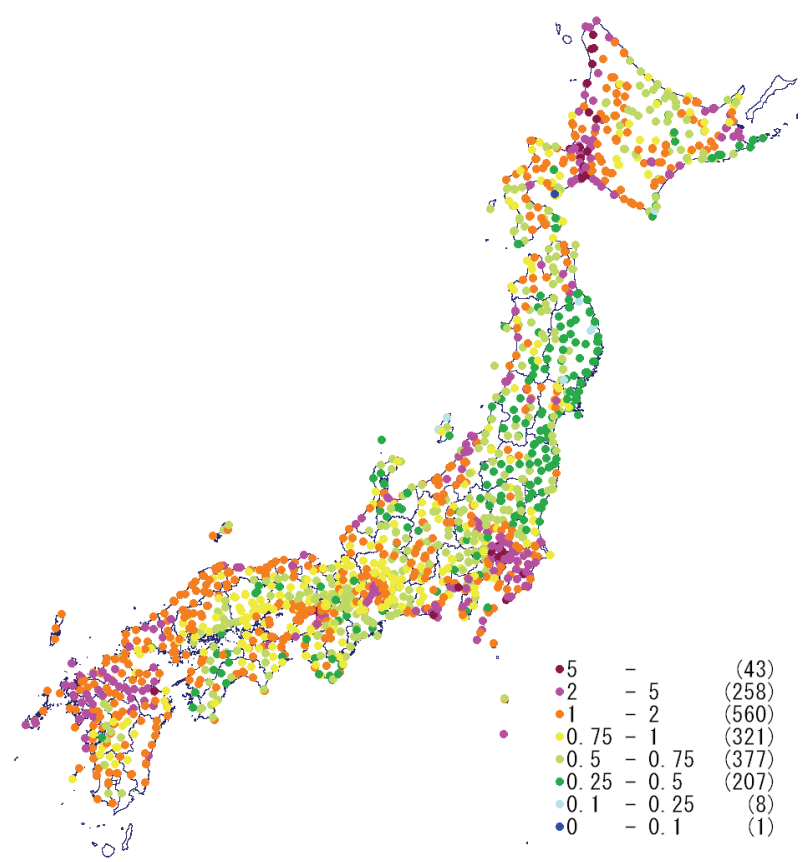

(b) $T_{n}=7[\mathrm{~s}]$

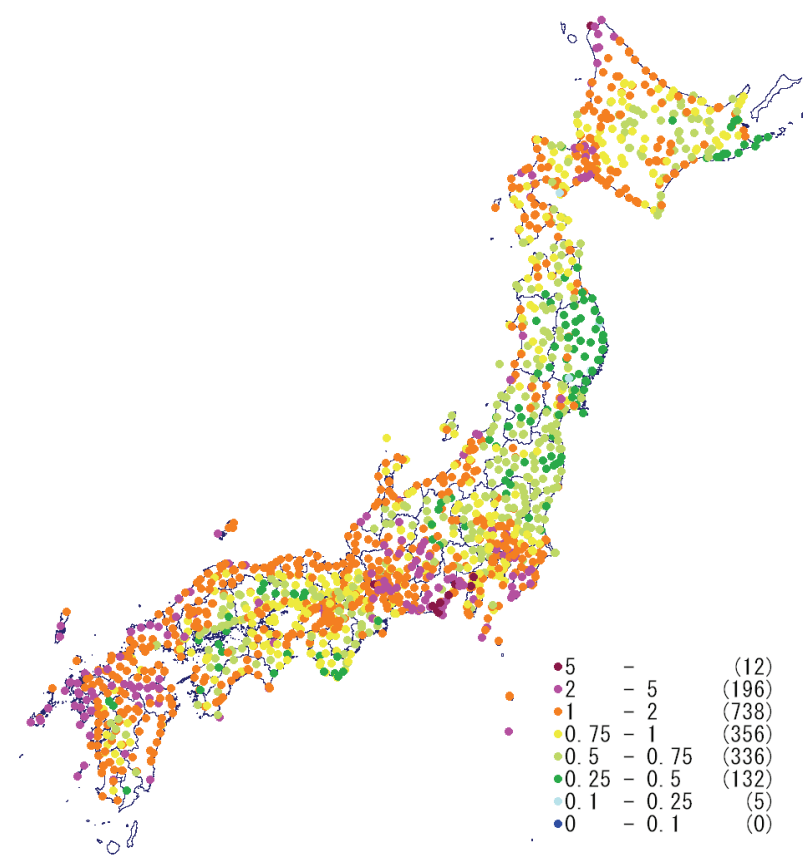

(d) $T_{n}=15[\mathrm{~s}]$

図-9 加速度応答スペクトル（減衰定数 1\%）の観測点補正倍率の分布（凡例の括弧内は該当する観測点数）

基盤岩類上面深度の分布 ${ }^{34)}$ と比較すると, 基盤岩類 が深い，すなわち堆積層が厚い主要な平野部（石 狩・勇払平野, 新潟平野, 関東平野, 濃尾平野, 大 阪平野など）で観測点補正倍率が大きい傾向が明ら かである，ただし，平野部であっても周期によって 違いがあり, 例えば関東平野では $T_{n}=7[\mathrm{~s}]$, 濃尾平野 では $T_{n}=3[\mathrm{~s}]$ の方が，観測点補正倍率が2以上の観測 点数が多く, 平野ごとにその規模や堆積層厚に応じ て卓越しやすい地震動の周期が異なることが読み取 れる. 観測点補正倍率は観測点直下の地盤構造のみ
で決定されるわけではなく, 盆地内では盆地全体の 構造，伝播経路特性にも影響されるものであるが, その地点で観測されるやや長周期地震動の増幅特性 を簡便に表現したものとして有用と考えられる.

\section{（5）全国の地点補正倍率}

図-9に示したように, やや長周期地震動が地盤に よって増幅される度合いは地域によって大きく異な っている，そのため，距離減衰式で平均的な地震動 強さを推定するだけでは十分ではなく, 対象地点に 


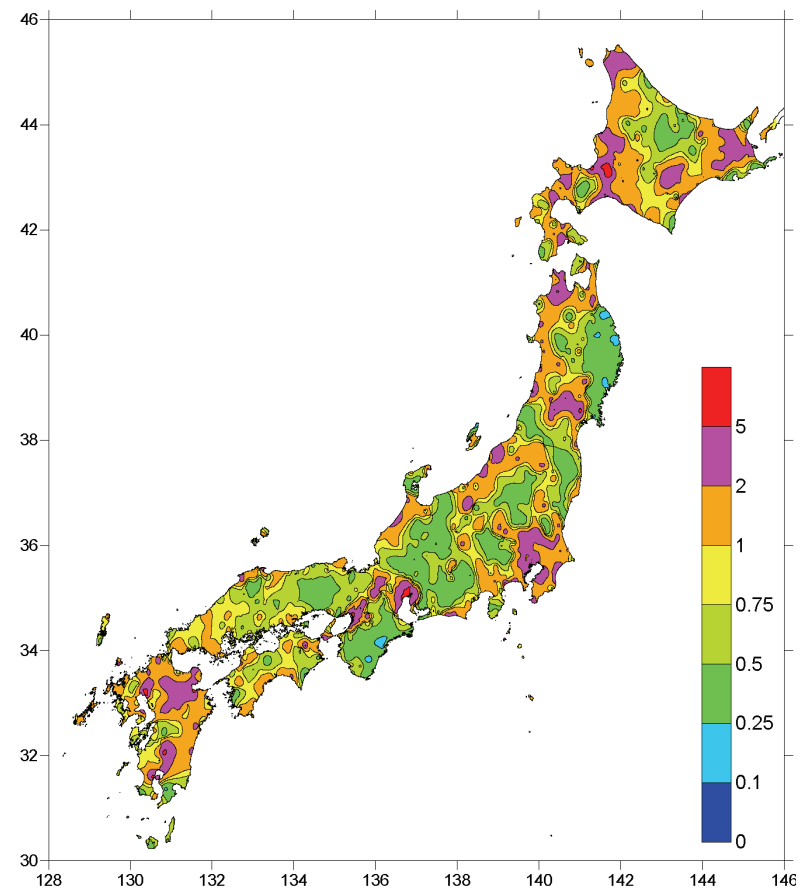

(a) $T_{n}=3[\mathrm{~s}]$

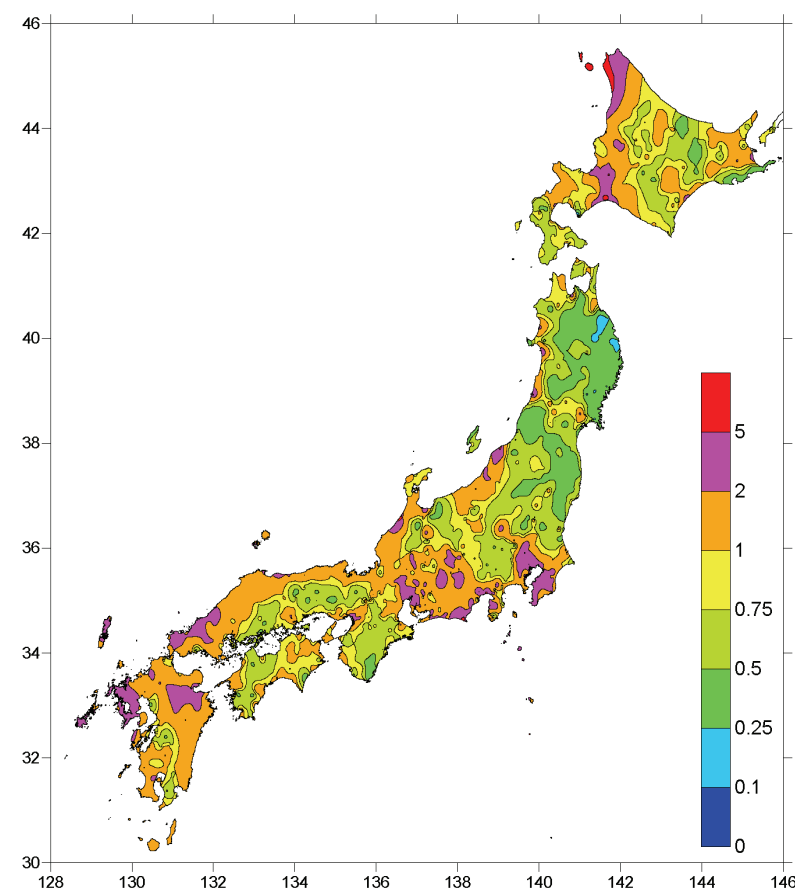

(c) $T_{n}=10[\mathrm{~s}]$

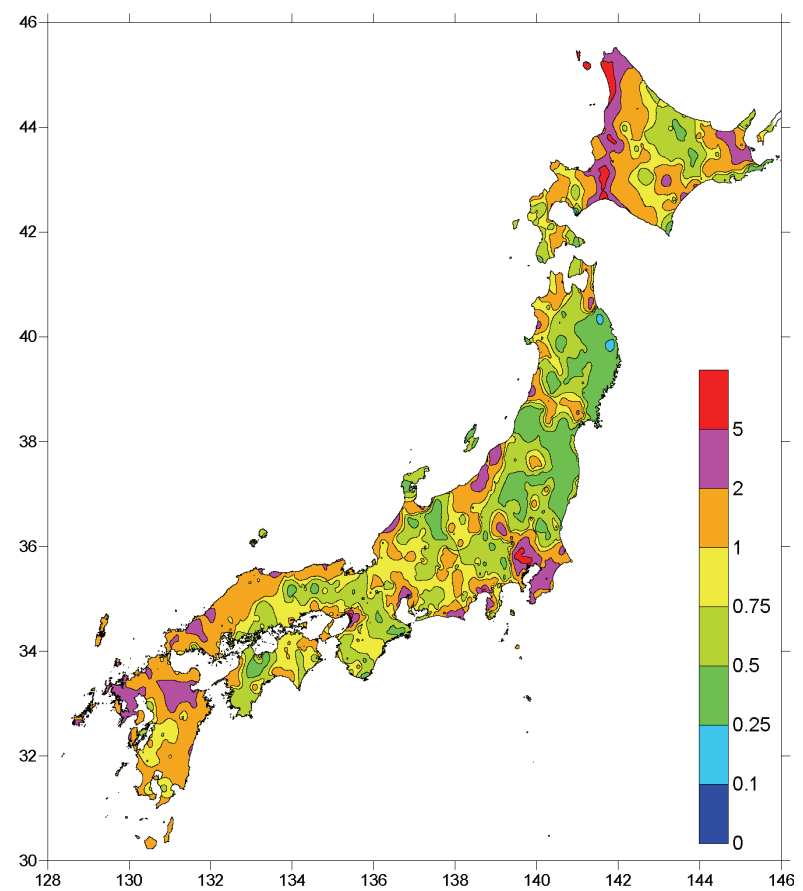

(b) $T_{n}=7[\mathrm{~s}]$

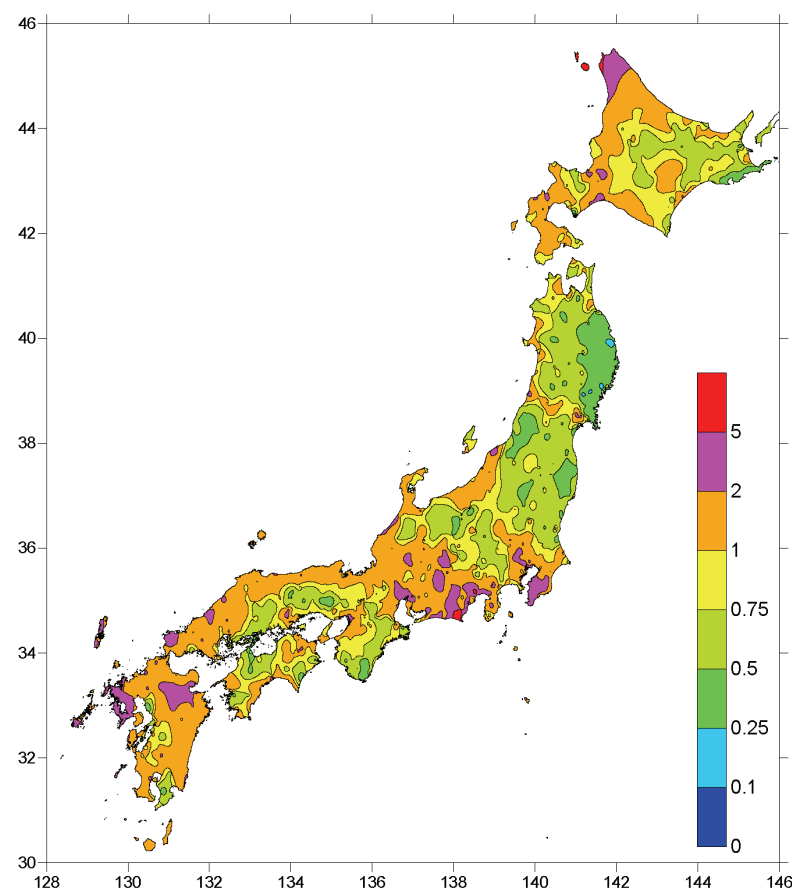

(d) $T_{n}=15[\mathrm{~s}]$

図-10 加速度応答スペクトル（減衰定数 $1 \%$ ）の距離減衰式の地点補正倍率の分布

おける地震動増幅特性を考慮しておく必要がある。 記録を使用した観測点については，上述の観測点 補正倍率を用いることができるが，任意の地点で地 震動増幅特性を考慮した地震動強さの推定を行うた めには，全国における補正值が必要となる。そこで， 加重平均法の一つである kriging法 ${ }^{35)} に よ り$ 観測点補 正倍率の空間補間を行い, 緯度 30 秒 $\times$ 経度 45 秒（約 $1[\mathrm{~km}] \times 1[\mathrm{~km}]$ ）の基準地域メッシュごとの補正值 （地点補正倍率とよぶ）を算出した。基準地域メッ シュ内に観測点がある場合には，観測点補正倍率を
そのままそのメッシュの地点補正倍率とした。

図-9 と同様, 減衰定数 $1 \%$ の加速度応答スペクト ル $\left(T_{n}=3,7,10,15[\mathrm{~s}]\right)$ の場合を例として, 地点補 正倍率の分布を図-10に示す。このような分布は, 減衰定数 $5 \%$ の加速度応答スペクトル，また加速度 フーリエスペクトルについても周期ごとに得られて いる。これらは全国を対象に, どこでどの程度, ど の周期のやや長周期地震動が増幅しやすいかを表現 したマップとなっている。ただし，特に山地などの 観測点が疎に分布している地域や地下構造が急変す 


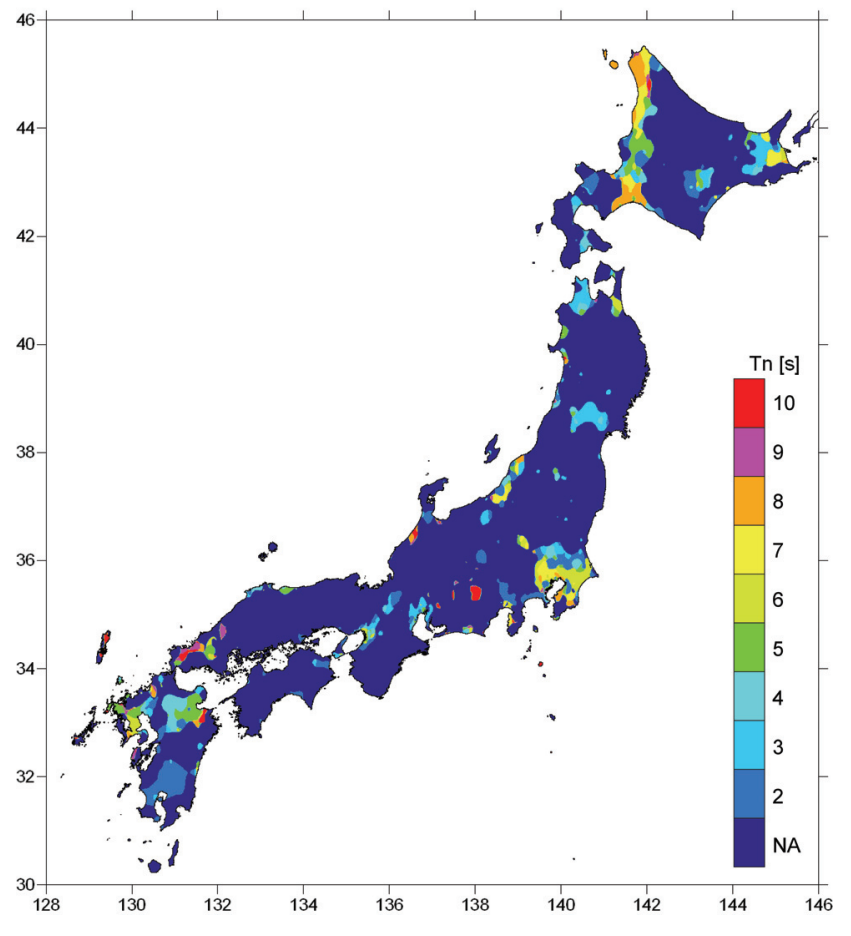

図-11地点補正倍率から評価した地盤の卓越周期

る地域では，空間補間によって算出した補正倍率の 精度が低くなっていることに注意しなければならな い.

上述のように，ある地点の地点補正倍率は，着目 する地震動の周期によって異なる。地点ごとに地点 補正倍率が最大となる周期をその地点における地震 動の卓越周期と考え, 分布図にしたものが図-11で ある。ここでは地点補正倍率が 2 10[s]の周期帯で 最大，かつ2以上となる周期を卓越周期とした。図 中NAは，2～10[s]の周期帯では地点補正倍率が2以 上にならない地点を示している。

この図により，平野ごとに特に地震動が増幅され やすい周期帯を特定することができ，例えば勇払平 野は8[s], 関東平野は6〜 7[s], 濃尾平野や大阪平野 は3〜4[s]である。また，九州地方や東北地方の一部， 諏訪盆地，境港周辺では，火山性の地形・地質や沖 積平野等の影響で周期数秒の地震動が増幅されるこ とが指摘されており ${ }^{36)}$, 既往の研究とも整合する結 果となっている。これら以外にも長い卓越周期を有 する地域が点在しているが，その理由や妥当性は今 後検討していく必要がある。

\section{（6）妥当性の検討}

土木学会・日本建築学会巨大地震災害対応共同研 究連絡会地震動部会の提供波 ${ }^{37)}$ のち, ここでの対 象周期帯域をほぼカバーしている釜江・川辺による 想定南海地震 $\left(M_{w} 8.55\right)$ の大阪における予測波 ${ }^{38), 39}$

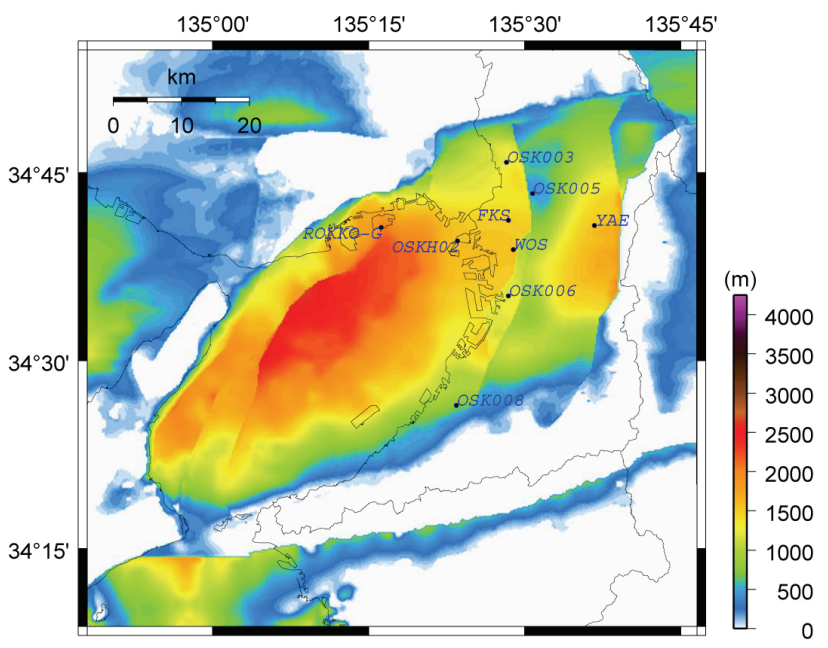

図-12 三次元差分法による地震動の計算に用いた地下構 造モデルの堆積盆地構造設定領域における基盤岩 上面深度と予測地点の位置 ${ }^{38)}$

と比較することにより，本研究で得られた距離減衰 式と地点補正倍率の妥当性を検討する.

この提供波は，大阪平野やフィリピン海プレート の構造に関する最新の知見を反映した9層からなる 地下構造モデルと, 地震調査研究推進本部地震調査 委員会によるモデルを参考に設定した南海地震の震 源モデルをもとに，三次元差分法により計算された ものである。差分格子間隔と地下構造から周期 2.5 [s] 以上が有効な計算結果とされており，2.5〜20[s] のバンドパスフィルターを施した9地点の時刻歴波 形が提供されている。図-12にその位置を示すが, これらはいずれも強震観測点の位置となっている. 図-12には，地下構造モデルの基盤岩上面深度も示 されており，この領域では詳細な堆積盆地構造がモ デル化されている.

提供波の加速度応答スペクトル（減衰定数 $1 \%$, 水平 2 成分合成）を計算し，本研究の距離減衰式に よる推定結果および地点補正倍率を考慮した推定結 果と比較したものを図-13に示す。これらのうち, OSKH002, ROKKO-GおよびWOSについては，本研 究では観測記録を用いていない観測点であり，空間 補間して得られた地点補正倍率を用いている。基盤 岩上面深度が $2[\mathrm{~km}]$ から $0[\mathrm{~km}]$ に急激に変化する, 地 下構造の急変部に位置しているROKKO-Gのように, 提供波が大幅に大きい点もあるが，ほとんどの地点 では，地点補正倍率を考慮することにより，提供波 とよく一致する加速度応答スペクトルが推定できて いることが分かる。

提供波のうち，鶴来らによる大阪府内23地点を対 象とした想定南海地震, 東南海地震, 南海・東南海 


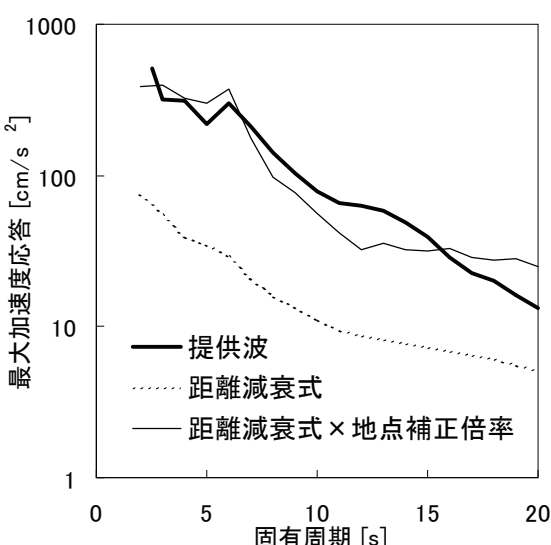

(a) FKS

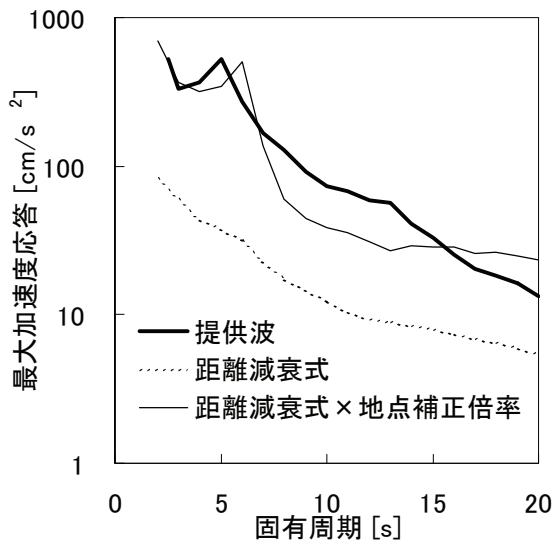

(d) OSK006

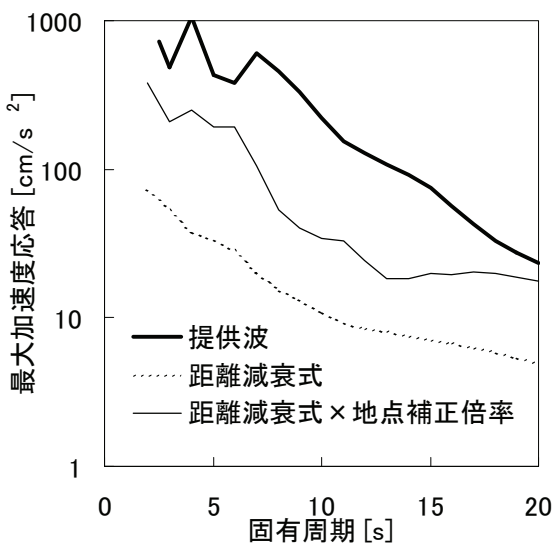

(g) ROKKO-G

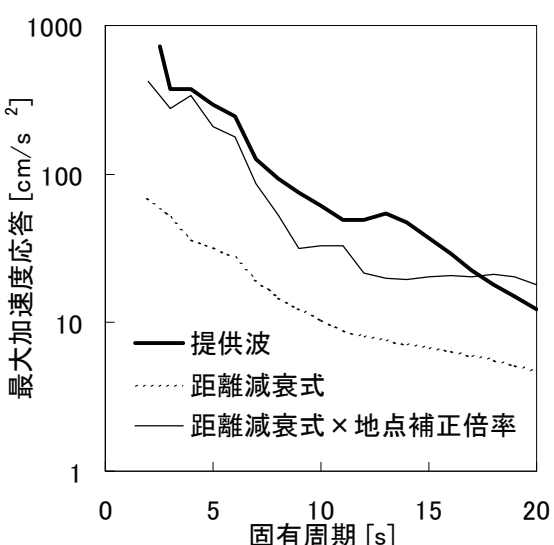

(b) OSK003

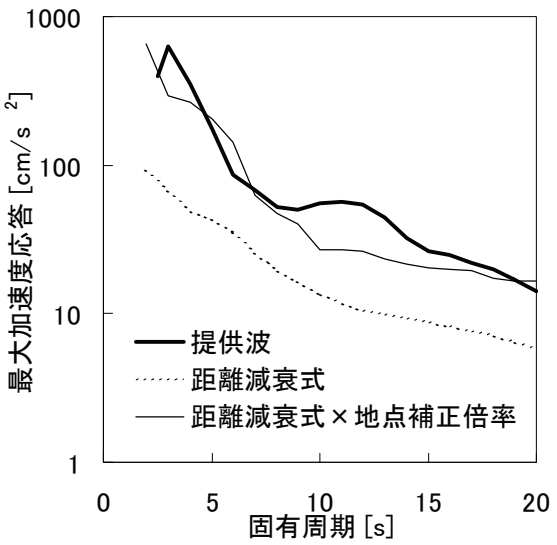

(e) OSK008

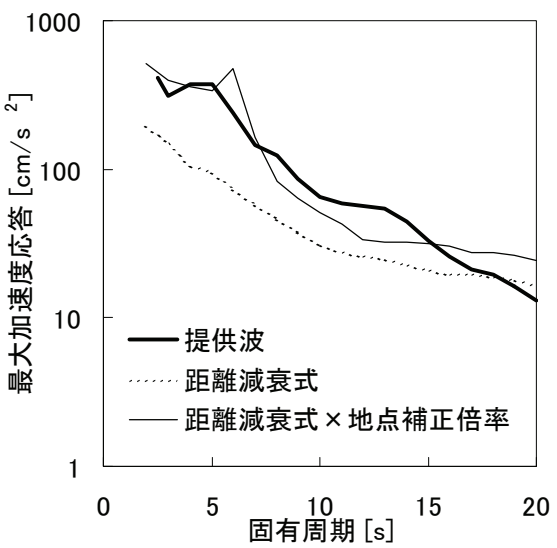

(h) WOS

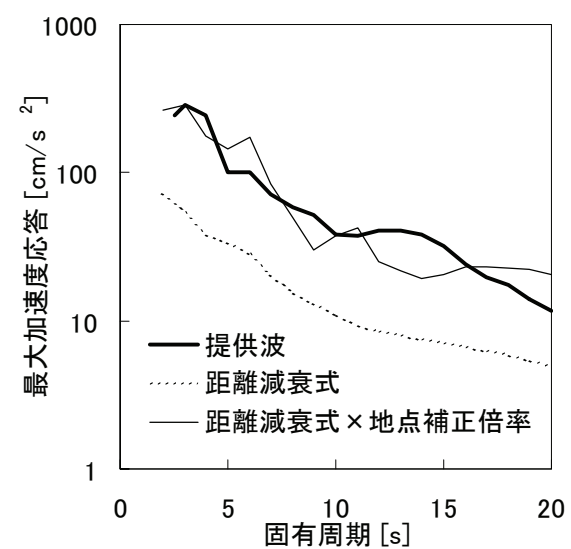

(c) OSK005

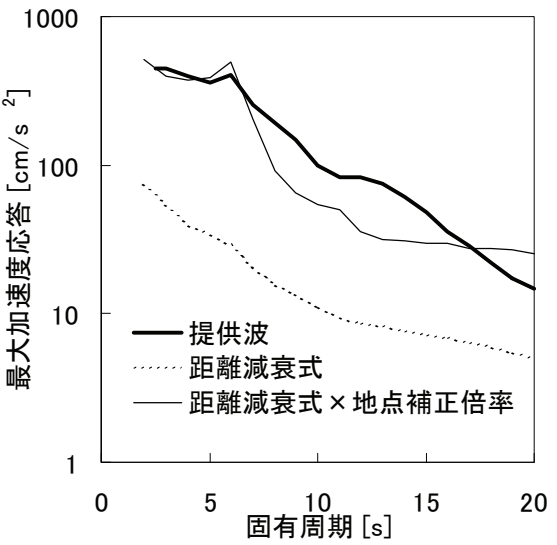

(f) OSKH002

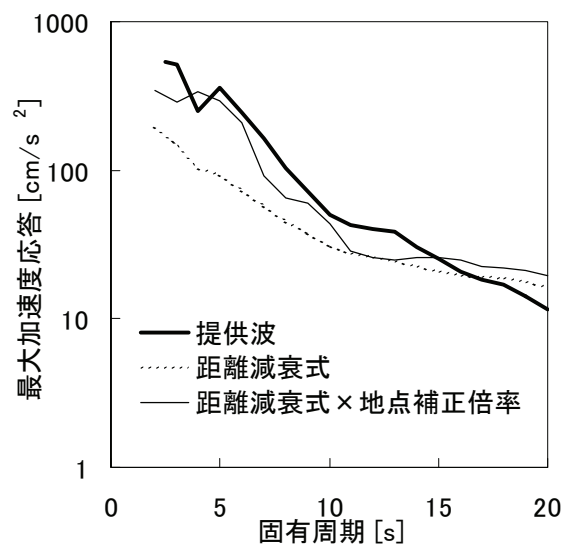

(i) YAE

図-13 提供波と距離減衰式および地点補正倍率から推定される加速度応答スペクトル（減衰定数 $1 \%$ ）の比較

地震 (それぞれ $\left.M_{w} 8.55,8.18,8.61\right)$ の予測波 ${ }^{40)}$, 39) と も同様の比較を行った。その結果，提供波が有効な 周期 $10[\mathrm{~s}]$ まででは, 距離減衰式と地点補正倍率によ り予測波とある程度一致する結果が得られた。ここ で対象とした想定南海地震等の $M_{w}$ は距離減衰式に 用いた記録の範囲外であるが，上記の結果から $M_{w}$ については，ある程度外挿して距離減衰式を利用す ることは可能と考えられる.

想定南海地震の大阪における地震動を予測した提
供波としては，この他に関口らによる予測波 ${ }^{41)}$ があ り，これら3者による提供波は同じ地点でもそれぞ れ卓越周期や振幅レベルが異なっている. その原因 は主に震源モデルの違いによるものと考察されてい

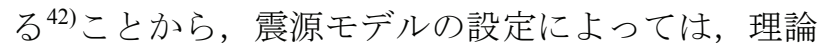
的手法で推定された地震動と本研究の距離減衰式と 地点補正倍率による推定結果があまり一致しないよ うな場合もあり得るものと考えられる。 


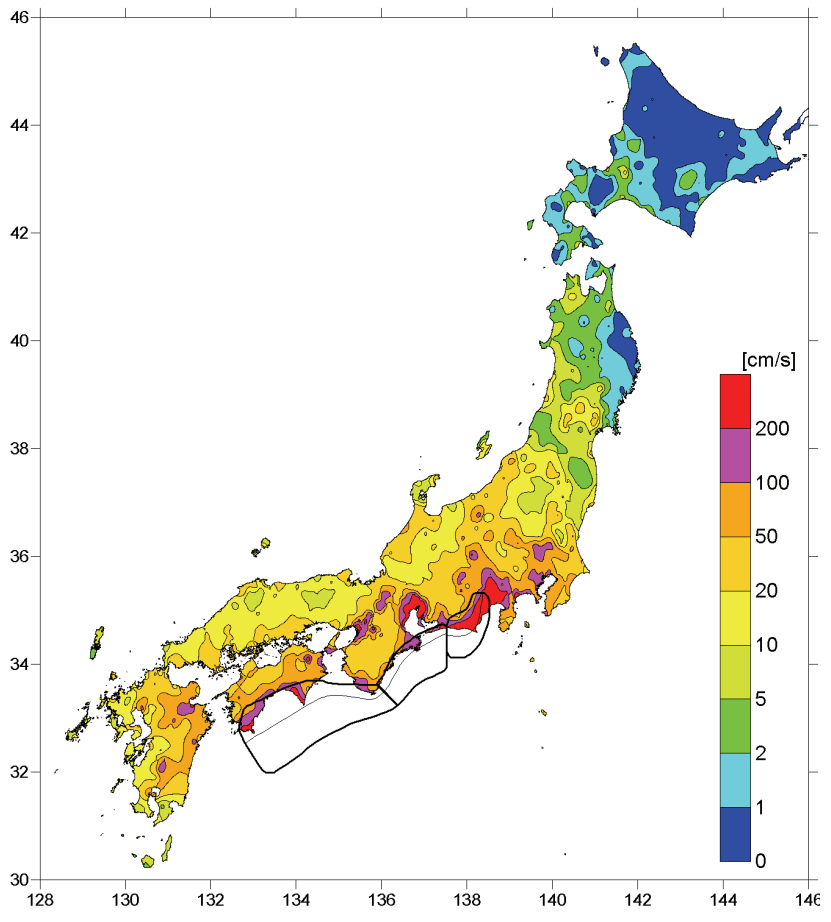

(a) $T_{n}=3[\mathrm{~s}]$

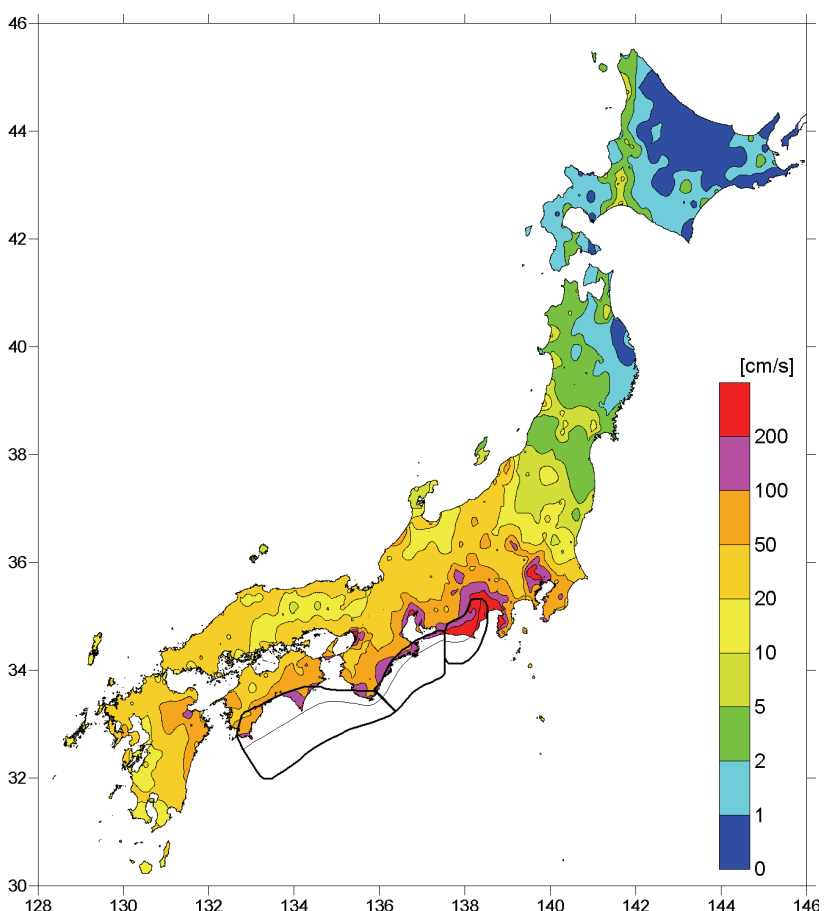

(b) $T_{n}=7[\mathrm{~s}]$

図-14 東海・東南海・南海連動地震のやや長周期地震動の試算結果（疑似速度応答スペクトル，減衰定数 $1 \%$ ）

\section{5. 想定地震のやや長周期地震動の試算}

ここまでに提案した距離減衰式と地点補正倍率の 適用例として, 発生が切迫していると言われる駿 河・南海トラフの地震のうち, 発生すればわが国周 辺で最大規模となる東海・東南海・南海連動地震を 対象としてやや長周期地震動を試算した。この地震 のモーメントマグニチュードは $M_{w} 8.5$ とし ${ }^{43)}$, 震源 域データ ${ }^{43)}$ に基づいて断層中心投影線を設定した。

図-14に例として，加速度応答スペクトル值から 換算した疑似速度応答スペクトル值 $p S_{V}[\mathrm{~cm} / \mathrm{s}]$ $\left(h=0.01, T_{n}=3,7[\mathrm{~s}]\right)$ の分布を示す. 太い害線は震 源域，震源域内の細い実線は断層中心投影線を示し ている，距離減衰式の作成に用いた記録は最大でも $M_{w} 8.2$ の地震で得られたものであり, また震源域か らの距離についても，使用した観測記録の範囲外 の外挿部分があることに注意が必要であるが，広域 にわたってやや振幅の大きい地震動が観測される可 能性が指摘できる.

このような広域の地震動推定を数值計算により実 施することは，現在でも計算機の能力や地盤データ の整備, モデル化の面で困難がともなうことから, 本研究で提示したサイトスペシフィック，かつ簡便 な予測を可能とする経験式は有用と考えられる。た だし, 個別地点の地震動は, 局所的な地盤構造にも 影響されるため, ここで試算したやや長周期地震動
は，距離減衰式を作成した際の統計解析や観測点補 正倍率の空間補間により平均化されたものであるこ とに注意する必要がある.

\section{6. 結 論}

本研究では，既往の観測記録をもとに，周期2 20 秒のやや長周期地震動の加速度応答スペクトル （減衰定数 $1 \%, 5 \%$ ） と加速度フーリエスペクトル を推定する距離減衰式を作成した。また，各周期の 観測点補正倍率を全国1775観測点で算出し，平野部 でやや長周期地震動の振幅が大きくなること，平野 ごとに大きく増幅される地震動の周期帯があり，地 下構造と関連づけられることを示した。この観測点 補正倍率を空間補間することにより，全国における 地点補正倍率を算定し，どこでどの程度，どの周期 のやや長周期地震動が増幅しやすいかを表現したマ ップを作成した。

この距離減衰式と地点補正倍率の妥当性を, 三次 元差分法で計算されたやや長周期地震動と比較する ことにより確認した. さらに, 東海・東南海・南海 連動地震発生時のやや長周期地震動を試算した.

地震の発生場所によって地震動の増幅率が異なる 場合もあること ${ }^{8)}{ }^{44)}$, また地下構造が急変する地域 を対象とした場合など，今後改善の必要はあるもの 
の, 本研究により, 日本全国の任意の点におけるや や長周期地震動が, 経験的手法によりサイトスペシ フィック，かつ簡便に推定できることが示された。

謝辞：本研究では, 関西地震観測研究協議会, 気象 庁，防災科学技術研究所（以上五十音順）並びに国 土交通省と北海道開発局が観測・収集した強震記録 を使用した。本研究はこれら強震観測の継続的な発 展と記録の蓄積に負うところが大きい。土木学会・ 日本建築学会巨大地震災害対応共同研究連絡会地震 動部会 (主査 : 入倉孝次郎愛知工業大学客員教授) では有益な御助言をいただいた。本研究で使用した 提供波は同部会により収集，整理されたものである。 京都大学釜江克宏教授には提供波および地下構造の 図を, 地域地盤環境研究所の鶴来雅人博士には提供 波を使用させていただいた。東海・東南海・南海地 震の震源域データは地震調査研究推進本部地震調査 委員会「全国を概観した地震動予測地図数值デー タ」を利用した。また，査読者各位の御意見は内容 の改善に大きく役立った。記して謝意を表する次第 である。

\section{付録}

表-A1〜A3にそれぞれ, 加速度応答スペクトル （減衰定数 $1 \% ， 5 \%$ ）および加速度フーリエスペク トルの距離減衰式（震源深さをパラメータとしない 場合）について, 固有周期ごとの回帰係数と回帰誤

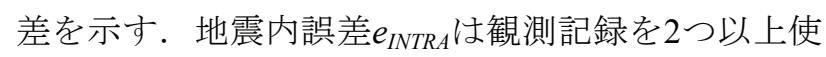
用している観測点のデータのみ用いた場合のばらつ きとし， $e_{T O T A L}$ はこの $e_{\text {INTRA }}$ を用いて式(13)で計算し た值を示す。また，基準観測点IWT009の観測点補 正值 $c_{j}$ を考慮することにより，サイト特性がない， すなわち地震基盤相当の距離減衰式が得られること から，これもあわせて示す。

\section{参考文献}

1) 土木学会 - 日本建築学会巨大地震災害対応共同研究連 絡会地震動部会 : 海溝型巨大地震を考える一広帯域強 震動の予測ーシンポジウム論文集, 2005.

2) 土木学会 ・ 日本建築学会巨大地震災害対応共同研究連 絡会地震動部会 : 海溝型巨大地震を考える一広帯域強 震動の予測2ーシンポジウム論文集, 2006.

3) 岡田成幸, 鏡味洋史 : 日本各地におけるやや長周期の 地盤特性の定量評価の試み, 日本建築学会論文報告集, Vol. 267, pp. 29-38, 1978.

4) Mamula, L., Kudo, K. and Shima, E.: Distribution of ground-motion amplification factors as a function of period (3-15 sec) in Japan, Bull. Earthq. Res. Inst., Vol. 59, pp. 467-500, 1984.

5) 井上涼介, 篠原哲也, 熊谷高, 小林浩二 : 気象庁強震 計記録の統計解析によるやや長周期摇れやすさの抽出, 第21回地震工学研究発表会講演概要, pp. 137-140, 1991.

6) 野田茂 : 気象庁 1 倍強震計記録を用いた長周期地盤震 動の地域特性について, 第21回地震工学研究発表会講 演概要, pp. 141-144, 1991.

7) 佐藤俊明, 宮腰淳一, 佐藤智美, 渡辺孝英, 植竹富一, 田中英朗 : 気象庁 87 型電磁式強震計記録の応答スペク トルの統計解析による各地気象台のやや長周期帯域 (周期 $1 \sim 10$ 秒)の摇れやすさ係数について, 第9回日本 地震工学シンポジウム論文集, pp.607-612, 1994.

8) 座間信作, 細川直史, 畑山健, 遠藤真 : やや長周期地 震動の早期予測システムの構築, 第11回日本地震工学 シンポジウム論文集, pp. 2307-2312, 2002.

9) 佐藤良輔編著：日本の地震断層パラメター・ハンドブ ック，鹿島出版会, 1989.

10) Mendoza, C. and Fukuyama, E.: The July 12, 1993, Hokkaido-Nansei-Oki, Japan, earthquake: Coseismic slip pattern from strong-motion and teleseismic recordings, $J$. Geophys. Res., Vol. 101, No. B1, pp. 791-801, 1996.

11) 菊地正幸, 金森博雄 : 広帯域地震記録による1994年北 海道東方沖地震の震源メカニズム, 月刊地球, Vol. 17, No. 5, pp. 322-328, 1995.

12) Nakamura, W. and Takeo, M.: Slip history of the 1994 Sanriku-Haruka-Oki, Japan, earthquake deduced from strong-motion data, Bull. Seism. Soc. Am., Vol. 87, pp. 918931, 1997.

13) Sekiguchi, H., Irikura, K. and Iwata, T.: Source inversion for estimating the continuous slip distribution on a faultintroduction of Green's functions convolved with a correction function to give moving dislocation effects in subfaults, Geophys. J. Int., Vol. 150, pp. 377-391, 2002.

14) 菊地正幸 : YCU地震学レポート, No.50, 1996.

15) Horikawa, H.: Earthquake doublet in Kagoshima, Japan: Rupture of asperities in a stress shadow, Bull. Seism. Soc. Am., Vol. 91, pp. 112-127, 2001.

16) Ide, S.: Source process of the 1997 Yamaguchi, Japan, earthquake analyzed in different frequency bands, Geophys. Res. Letters, Vol. 26, 1999.

17) Nakahara, H., Nishimura, T., Sato, H., Ohtake, M., Kinoshita, S. and Hamaguchi, H.: Broadband source process of the 1998 Iwate Prefecture, Japan, earthquake as revealed from inversion analyses of seismic waveforms and envelopes, Bull. Seism. Soc. Am., Vol. 92, pp. 1708-1720, 
表-A1 加速度応答スペクトル（減衰定数 1\%）の距離減衰式の回帰係数と回帰誤差

(a) 海溝性地震

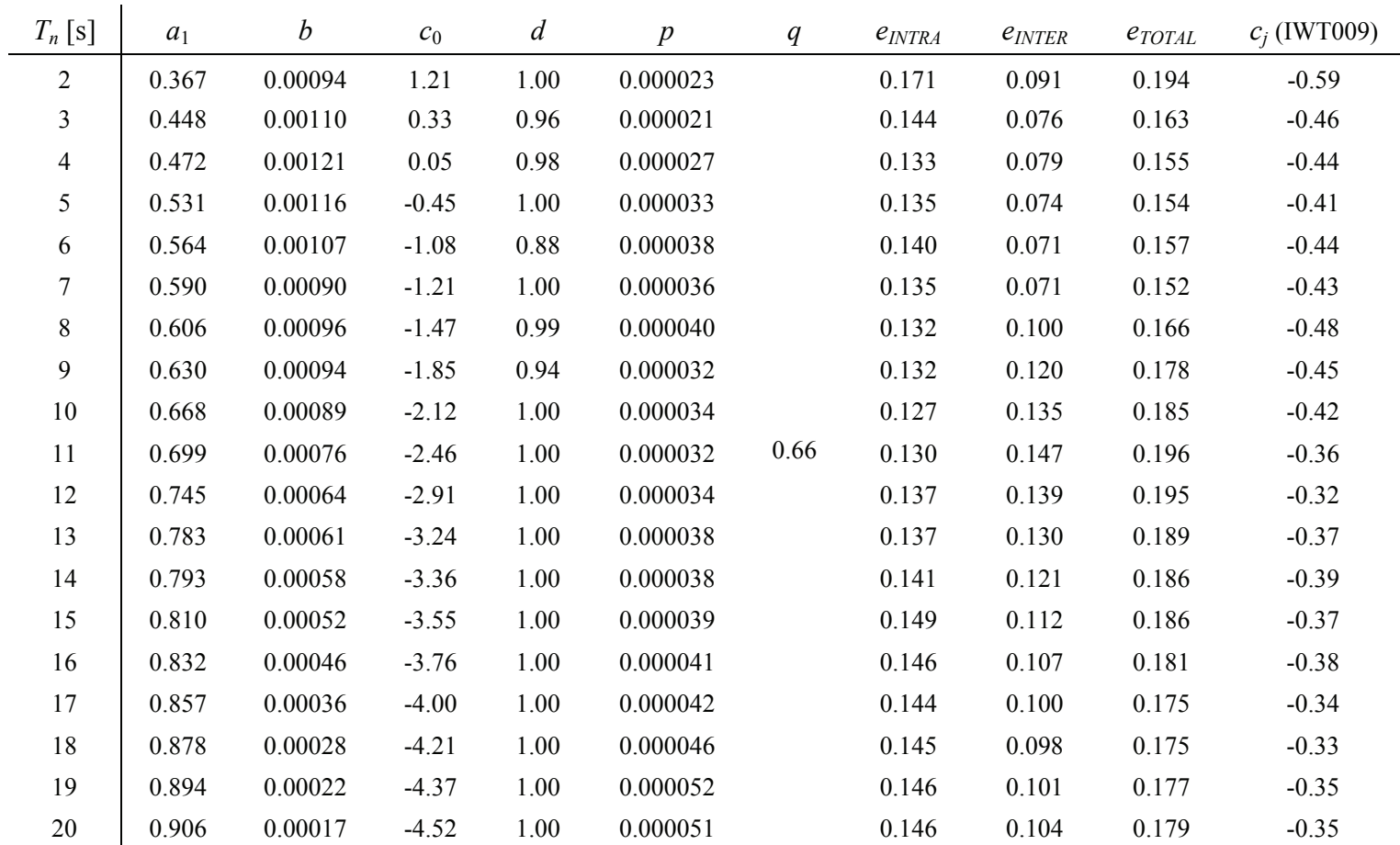

\section{(b) 内陸地震}

\begin{tabular}{|c|c|c|c|c|c|c|c|c|c|c|}
\hline$T_{n}[\mathrm{~s}]$ & $a_{1}$ & $b$ & $c_{0}$ & $d$ & $p$ & $q$ & $e_{I N T R A}$ & $e_{I N T E R}$ & $e_{\text {TOTAL }}$ & $c_{j}$ (IWT009) \\
\hline 2 & 0.666 & 0.00074 & -1.39 & 0.79 & 0.000023 & & 0139 & 0.057 & 0.150 & -0.59 \\
\hline 3 & 0.741 & 0.00049 & -2.12 & 0.80 & 0.000021 & & 0.134 & 0.108 & 0.172 & -0.46 \\
\hline 4 & 0.796 & 0.00083 & -2.93 & 0.64 & 0.000027 & & 0.127 & 0.120 & 0.174 & -0.44 \\
\hline 5 & 0.897 & 0.00071 & -3.81 & 0.59 & 0.000033 & & 0.132 & 0.115 & 0.175 & -0.41 \\
\hline 6 & 0.926 & 0.00060 & -4.18 & 0.56 & 0.000038 & & 0.134 & 0.099 & 0.167 & -0.44 \\
\hline 7 & 0.964 & 0.00071 & -4.64 & 0.50 & 0.000036 & & 0.132 & 0.093 & 0.161 & -0.43 \\
\hline 8 & 0.998 & 0.00065 & -4.98 & 0.51 & 0.000040 & & 0.133 & 0.089 & 0.160 & -0.48 \\
\hline 9 & 0.993 & 0.00034 & -5.04 & 0.55 & 0.000032 & & 0.139 & 0.082 & 0.162 & -0.45 \\
\hline 10 & 1.024 & 0.00033 & -5.34 & 0.56 & 0.000034 & & 0.138 & 0.082 & 0.160 & -0.42 \\
\hline 11 & 1.064 & 0.00039 & -5.71 & 0.55 & 0.000032 & 0.66 & 0.139 & 0.081 & 0.161 & -0.36 \\
\hline 12 & 1.081 & 0.00036 & -5.90 & 0.56 & 0.000034 & & 0.132 & 0.078 & 0.153 & -0.32 \\
\hline 13 & 1.080 & 0.00033 & -5.95 & 0.58 & 0.000038 & & 0.130 & 0.079 & 0.152 & -0.37 \\
\hline 14 & 1.087 & 0.00031 & -6.04 & 0.60 & 0.000038 & & 0.128 & 0.079 & 0.150 & -0.39 \\
\hline 15 & 1.089 & 0.00031 & -6.10 & 0.61 & 0.000039 & & 0.128 & 0.079 & 0.150 & -0.37 \\
\hline 16 & 1.086 & 0.00027 & -6.15 & 0.62 & 0.000041 & & 0.130 & 0.077 & 0.151 & -0.38 \\
\hline 17 & 1.088 & 0.00031 & -6.22 & 0.62 & 0.000042 & & 0.131 & 0.078 & 0.152 & -0.34 \\
\hline 18 & 1.084 & 0.00032 & -6.24 & 0.63 & 0.000046 & & 0.132 & 0.078 & 0.153 & -0.33 \\
\hline 19 & 1.076 & 0.00032 & -6.23 & 0.64 & 0.000052 & & 0.134 & 0.078 & 0.155 & -0.35 \\
\hline 20 & 1.065 & 0.00034 & -6.22 & 0.64 & 0.000051 & & 0.136 & 0.078 & 0.157 & -0.35 \\
\hline
\end{tabular}

2002.

18) 岩田知孝，関口春子：2000年鳥取県西部地震の震源過 程と震源域強震動, 第11回日本地震工学シンポジウム 論文集，pp. 125-128，2002.

19) 青井真, 関口春子, 功刀卓, 本多亮, 藤原広行 : 近地 強震動記録による宮城県北部(2003/07/26, 7:13)の地震 の震源インバージョン（暫定）, http://www.k-net.bosai. go.jp/k-net/news/miyagi_200307260713/, 2003.
20) Koketsu, K., Hikima, K., Miyazaki, S. and Ide, S.: Joint inversion of strong motion and geodetic data for the source process of the 2003 Tokachi-oki, Hokkaido, earthquake, Earth, Planets and Space, Vol. 56, pp. 329-334, 2004.

21) 東京大学地震研究所地震予知情報センター : EIC地震 学ノート, No.153, 2004.

22) Hikima, K. and Koketsu, K.: Rupture processes of the 2004 Chuetsu (mid-Niigata prefecture) earthquake, Japan: A 
表-A2 加速度応答スペクトル（減衰定数 5\%）の距離減衰式の回帰係数と回帰誤差

(a) 海溝性地震

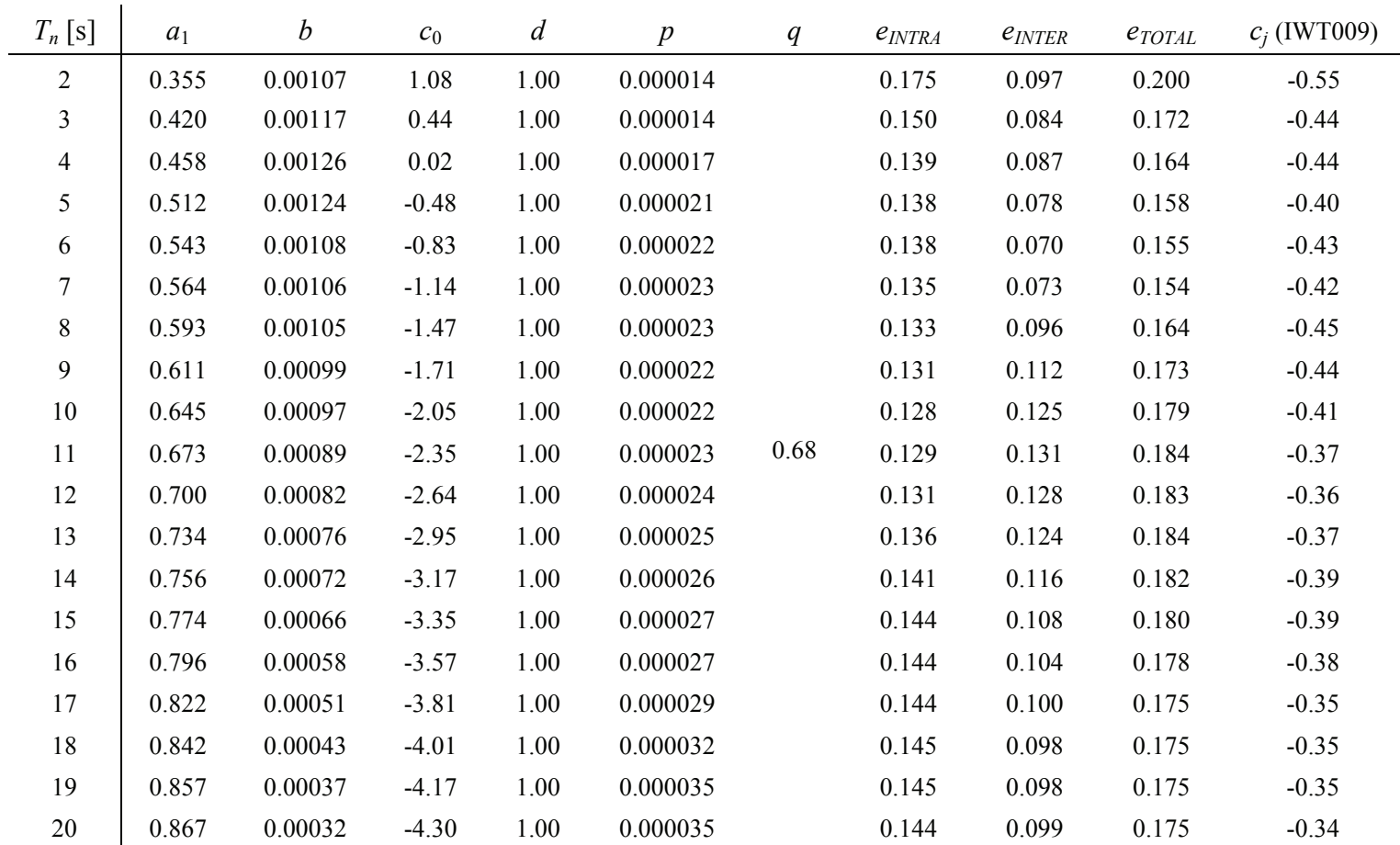

\section{(b) 内陸地震}

\begin{tabular}{|c|c|c|c|c|c|c|c|c|c|c|}
\hline$T_{n}[\mathrm{~s}]$ & $a_{1}$ & $b$ & $c_{0}$ & $d$ & $p$ & $q$ & $e_{I N T R A}$ & $e_{I N T E R}$ & $e_{\text {TOTAL }}$ & $c_{j}$ (IWT009) \\
\hline 2 & 0.663 & 0.00073 & -1.52 & 0.82 & 0.000014 & & 0.138 & 0.058 & 0.150 & -0.55 \\
\hline 3 & 0.721 & 0.00047 & -2.04 & 0.86 & 0.000014 & & 0.137 & 0.105 & 0.173 & -0.44 \\
\hline 4 & 0.770 & 0.00077 & -2.74 & 0.73 & 0.000017 & & 0.126 & 0.119 & 0.173 & -0.44 \\
\hline 5 & 0.858 & 0.00071 & -3.54 & 0.67 & 0.000021 & & 0.130 & 0.117 & 0.175 & -0.40 \\
\hline 6 & 0.905 & 0.00074 & -4.07 & 0.60 & 0.000022 & & 0.133 & 0.107 & 0.171 & -0.43 \\
\hline 7 & 0.938 & 0.00073 & -4.48 & 0.56 & 0.000023 & & 0.135 & 0.101 & 0.169 & -0.42 \\
\hline 8 & 0.968 & 0.00061 & -4.78 & 0.57 & 0.000023 & & 0.137 & 0.096 & 0.167 & -0.45 \\
\hline 9 & 0.979 & 0.00047 & -4.96 & 0.58 & 0.000022 & & 0.142 & 0.090 & 0.168 & -0.44 \\
\hline 10 & 1.005 & 0.00041 & -5.21 & 0.59 & 0.000022 & & 0.142 & 0.088 & 0.167 & -0.41 \\
\hline 11 & 1.031 & 0.00037 & -5.47 & 0.60 & 0.000023 & 0.68 & 0.143 & 0.086 & 0.167 & -0.37 \\
\hline 12 & 1.046 & 0.00035 & -5.63 & 0.61 & 0.000024 & & 0.139 & 0.083 & 0.162 & -0.36 \\
\hline 13 & 1.050 & 0.00034 & -5.72 & 0.62 & 0.000025 & & 0.137 & 0.082 & 0.160 & -0.37 \\
\hline 14 & 1.050 & 0.00032 & -5.78 & 0.63 & 0.000026 & & 0.133 & 0.082 & 0.156 & -0.39 \\
\hline 15 & 1.048 & 0.00029 & -5.80 & 0.65 & 0.000027 & & 0.133 & 0.081 & 0.156 & -0.39 \\
\hline 16 & 1.045 & 0.00029 & -5.85 & 0.65 & 0.000027 & & 0.133 & 0.081 & 0.156 & -0.38 \\
\hline 17 & 1.048 & 0.00028 & -5.91 & 0.66 & 0.000029 & & 0.134 & 0.081 & 0.157 & -0.35 \\
\hline 18 & 1.049 & 0.00029 & -5.96 & 0.67 & 0.000032 & & 0.134 & 0.081 & 0.157 & -0.35 \\
\hline 19 & 1.044 & 0.00029 & -5.97 & 0.68 & 0.000035 & & 0.135 & 0.081 & 0.157 & -0.35 \\
\hline 20 & 1.039 & 0.00028 & -5.97 & 0.69 & 0.000035 & & 0.136 & 0.081 & 0.158 & -0.34 \\
\hline
\end{tabular}

series of events in a complex fault system, Geophys. Res. Letters, Vol. 32, 2005.

23) 東京大学地震研究所地震予知情報センター : EIC地震 学ノート, No. 158+, 2004.

24) Kobayashi, R., Miyazaki, S. and Koketsu, K.: Source processes of the 2005 West Off Fukuoka Prefecture earthquake and its largest aftershock inferred from strong motion and 1-Hz GPS data, Earth, Planets and Space, Vol.
58, pp. 57-62, 2006

25) 東京大学地震研究所地震予知情報センター：EIC地震 学ノート, No. 168+, 2005.

26) 佐々木康, 田村敬一, 相沢興, 高橋和之 : 気象庁一倍 強震計記録に基づく長周期地震動特性の解析一（その 2）1968年日向灘地震記録の解析一，土木研究所資料, 第2245号, 1985 .

27) 佐々木康，田村敬一，相沢興：気象庁一倍強震計記録 
表-A3 加速度フーリエスペクトルの距離減衰式の回帰係数と回帰誤差

(a) 海溝性地震

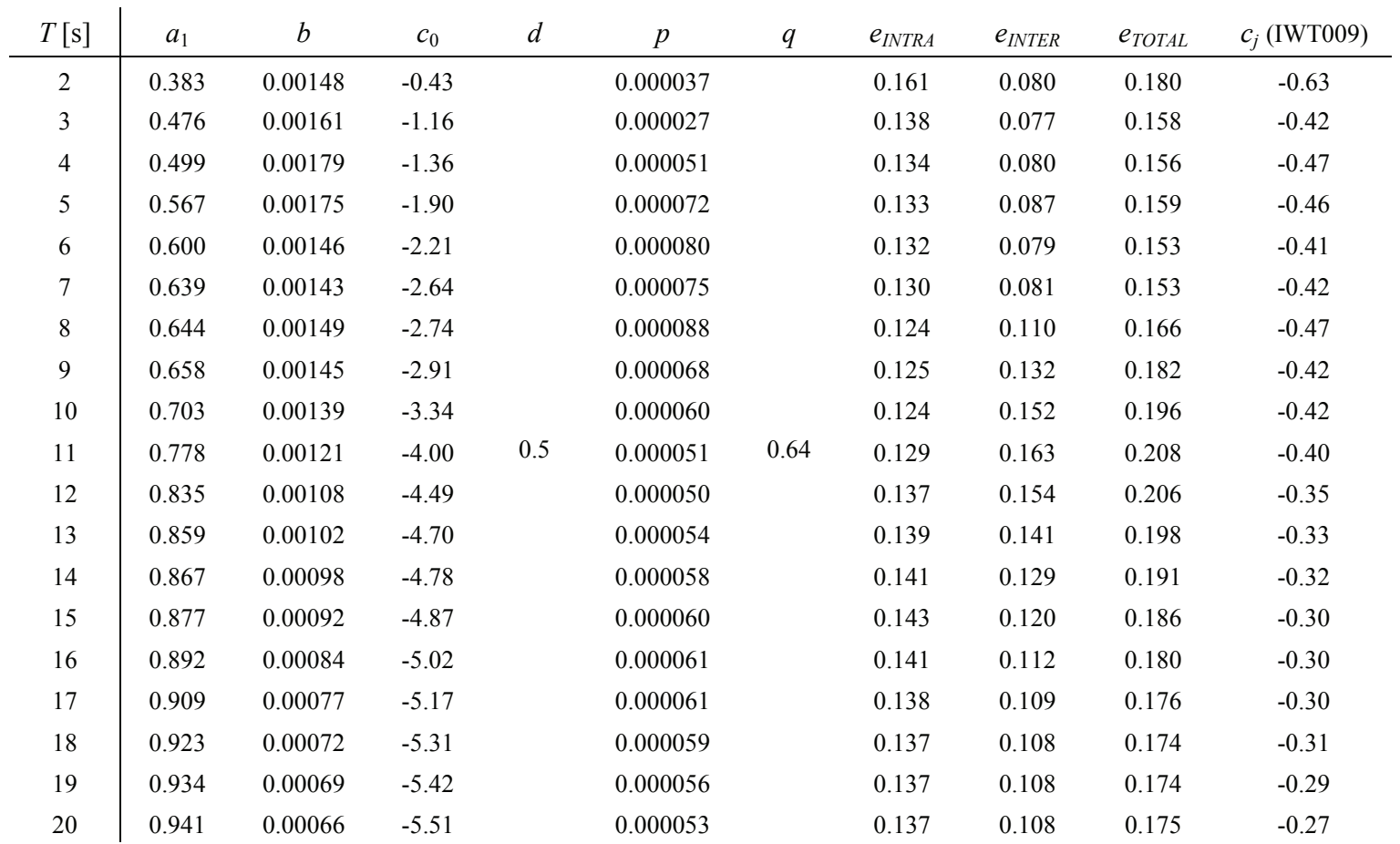

(b) 内陸地震

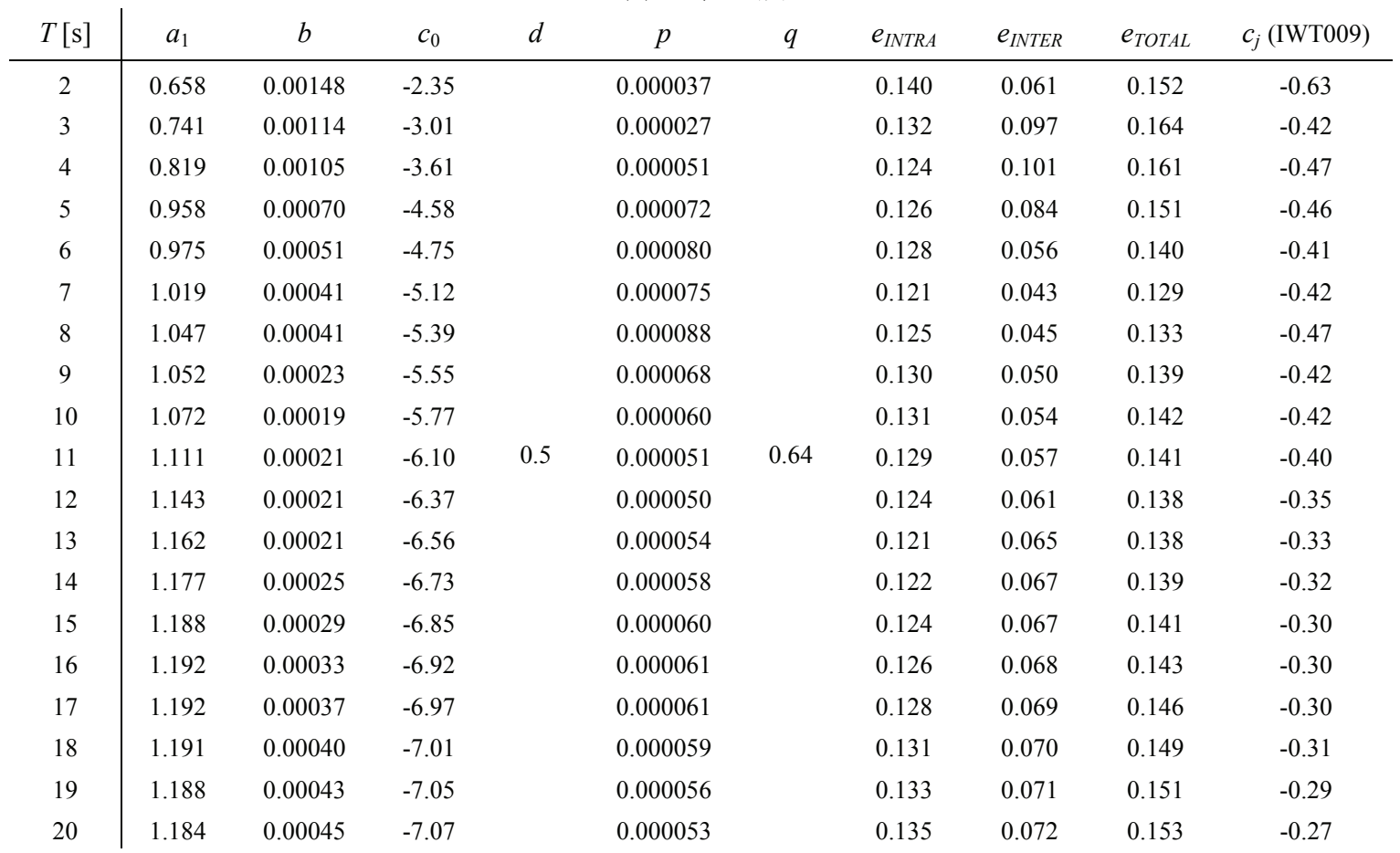

に基づく長周期地震動特性の解析一（その4）1964年 新潟地震記録の解析一, 土木研究所資料，第2493号， 1987.

28) 佐々木康，田村敬一，相沢興，高橋和之：気象庁一倍 強震計の記録精度に関する実験的検討，土木研究所資 料, 第2386号, 1986.

29) Fukushima, Y. and Tanaka, T.: A new attenuation relation for peak horizontal acceleration of strong earthquake ground motion in Japan, Bull. Seism. Soc. Am., Vol. 80, pp. 757-783, 1990.

30) 片岡正次郎, 佐藤智美, 松本俊輔, 日下部毅明 : 短周 期レベルをパラメータとした地震動強さの距離減衰式, 土木学会論文集A, Vol. 62, No. 4, pp. 740-757, 2006.

31) 佐藤智美，巽誉樹：全国の強震記録に基づく内陸地震 と海溝性地震の震源・伝播 - サイト特性, 日本建築学 会構造系論文集，Vol. 556, pp. 15-24, 2002. 
32) 佐藤俊明, 佐藤智美, 宮腰淳一, 渡辺孝英, 植竹富一, 田中英朗：表面波が卓越する周期 $2 \sim 20$ 秒のやや長周 期地震動の距離減衰特性に関する基礎的研究一距離減 衰式の整理と理論地震動を用いた検討一, 日本建築学 会構造系論文集，第463号, pp. 39-49, 1994.

33) 佐々木康, 田村敬一, 相沢興 : 気象庁一倍強震計記録 に基づく長周期地震動特性の解析一（その5）1978年 宮城県沖地震記録の解析一, 土木研究所資料，第 2664 号, 1988.

34) 藤原広行, 河合伸一, 青井真, 先名重樹, 大井昌弘, 松山尚典, 岩本鋼司, 鈴木晴彦, 早川譲 : 強震動評価 のための深部地盤構造全国初期モデル，第12回日本地 震工学シンポジウム論文集, pp. 1466-1469, 2006.

35) Golden Software, Inc.: Surfer user’s guide, 2002.

36) 野津厚, 長尾毅 : スペクトルインバージョンに基づく 全国の港湾等におけるサイト増幅特性，港湾空港技術 研究所資料, No. 1112, 2005.

37）（社）土木学会：第1章地震動部会, 巨大地震災害一 の対応検討特別委員会報告書, pp. 2-13, 2006.

38) 釜江克宏, 川辺秀憲 : 想定南海地震の強震動予測, 巨 大地震災害への対応検討特別委員会地震動部会第11回 資料, 2005.

39）（社）土木学会：付録 地震動提供波概説文，巨大地
震災害への対応検討特別委員会報告書, 2006 .

40) 鶴来雅人, 趙伯明, Petukhin Anatoly, 香川敬生 : 南 海・東南海地震の大阪府域における強震動予測, 土木 学会構造工学論文集, Vol.51A,pp. 501-512, 2005.

41) 関口春子, 吉見雅行, 堀川晴央, 吉田邦一: 海溝型巨 大地震の広帯域地震動予測のためのマルチスケール不 均質モデルと南海地震への適用, 海溝型巨大地震を考 える一広帯域強震動の予測 2 -シンポジウム論文集, pp. 61-73, 2006.

42) 岩田知孝, 岩城麻子, 関口春子, 吉見雅行 : 地域特性 を反映した長周期地震動, 日本建築学会構造委員会高 機能社会耐震工学ワーキンググループ, 長周期地震動 対策に関する公開研究集会, pp. 1-52, 2008.

43) 地震調査研究推進本部地震調查委員会 : 「全国を概観 した地震動予測地図」報告書（分冊1）－確率論的地 震動予測地図の説明－，2005.

44) 片岡正次郎, 日下部毅明, 松本俊輔 : やや長周期地震 動の距離減衰式と増幅率の地域性, 海溝型巨大地震を 考える一広帯域強震動の予測2ーシンポジウム論文集, pp. 13-18, 2006.

(2007. 7.5 受付)

\title{
ATTENUATION RELATIONSHIPS AND AMPLIFICATION MAP FOR GROUND MOTION IN RATHER-LONG PERIOD RANGE
}

\author{
Shojiro KATAOKA, Shunsuke MATSUMOTO, \\ Takaaki KUSAKABE and Nobuhiko TOYAMA
}

\begin{abstract}
Attenuation relationships are proposed for acceleration response spectrum and Fourier spectrum of ground motion in rather-long period range using strong motion records observed in Japan. Amplification maps are also developed to compensate the attenuation relationships for site amplification characteristics. Comparisons with the ground motion calculated by a three-dimensional finite difference method validate the attenuation relationships and amplification maps. Ground motion during hypothetical great earthquakes is estimated by the present method, showing the method enables site-specific ground motion prediction at arbitrary sites all over Japan.
\end{abstract}

